\title{
LA PARTICIPACIÓN POLÍTICA DIRECTA EN EL PROCESO CONSTITUYENTE ESPAÑOL DE 1977-78
}

\section{DIRECT POLITICAL PARTICIPATION IN THE SPANISH CONSTITUENT PROCESS OF 1977-78}

\author{
José Eduardo Illueca Ballester \\ Universidad Nacional de Educación a Distancia
}

SUMARIO: I. INTRODUCCIÓN. II. EL PROCESO CONSTITUYENTE ESPAÑOL EN EL CONTEXTO HISTÓRICO DE LA TRANSICIÓN POLÍTICA. III. AVATARES DE LA PARTICIPACIÓN POLÍTICA DIRECTA A LO LARGO DEL ITER CONSTITUYENTE. 3.1. Los instrumentos de participación política directa en el Anteproyecto de Constitución. 3.2. Los referendos de ámbito territorial en el debate constituyente sobre el modelo territorial del Estado. 3.3. Desmantelamiento del programa participativo de la ponencia por la Comisión de Asuntos Constitucionales y Libertades Públicas. 3.4. El trámite en el Senado. 3.5 La actuación de la Comisión Mixta Congreso-Senado: último golpe a la participación política directa. IV. EL INSUFICIENTE RECONOCIMIENTO CONSTITUCIONAL DE LA PARTICIPACIÓN POLÍTICA DIRECTA. 4.1. Las razones de los constituyentes. 4.2. Los argumentos de los constituyentes. 4.3. Las tesis del riesgo. V. CONCLUSIONES.

Resumen: En 1978, el constituyente español optó finalmente por una regulación restrictiva de la participación política directa, en contraste con la amplia recepción que había contemplado el Anteproyecto de Constitución. Una aproximación a los debates sobre esta materia durante el proceso constituyente español permite explicar lo ocurrido en función de las circunstancias históricas del momento y de factores ligados a la dinámica del mismo proceso constituyente. Desde esta perspectiva histórica, se observa que el tratamiento constitucional de la participación política directa obedeció a causas transitorias y no estructurales. $\mathrm{Su}$ adecuación a la sociedad española actual, en esta medida, debería seguramente ser revisada.

Abstract: Abstract: In 1978, the Spanish constituent power finally opted for a restrictive regulation of direct political participation, in contrast to the wide reception that the first Draft of the Constitution had contemplated. An approach to the debates on this matter during the Spanish constituent process allows for an explaination about what happened in terms of the historical circumstances of the time and the factors related to the dynamics of the same constituent process. Observed from this historical perspective, the constitutional treatment of direct political participation obeys to transitory and non-structural causes. Consequently, its adaptation to the current Spanish society should definitely be revised.

Palabras clave: Proceso constituyente español, participación política directa, referendo, iniciativa legislativa popular. 
Key Words: Spanish constituent process, direct political participation, referendum, popular legislative initiative.

\section{INTRODUCCIÓN}

Las constituciones son fruto de un momento histórico. Las determinaciones que contienen, aunque llamadas a regir la convivencia social y politica de un país hacia el futuro, guardan una relación genética indudable con las circunstancias del tiempo en el que nacen, tienen una explicación acorde con las mismas y cumplen una función concreta en el sistema jurídico-político que la Constitución instaura. Asi, los impulsos reactivos frente a un régimen anterior rechazado por el nuevo poder constituyente, la correlación de fuerzas en el seno de la asamblea constituyente, las tensiones políticas propias de cada época, las modas constitucionales imperantes, la naturaleza y la composición de la comisión redactora de la ponencia constitucional o la dinámica de los debates en la asamblea son factores - entre otros - que condicionan el resultado constitucional. Por ello, el sentido y el significado de las normas constitucionales solo son aprehensibles por completo cuando se introduce en el análisis la perspectiva histórica, y también es entonces cuando se nos muestran de modo más claro las posibilidades de evolución o desarrollo del texto constitucional para adecuarlo a nuevas situaciones que no podían ser previstas en el momento constituyente.

Nuestro propósito es, desde la óptica apuntada, indagar sobre los condicionantes que influyeron, a lo largo del proceso constituyente español de 1977-78, en la parca recepción final de la participación política directa en el texto de nuestra Constitución, generalmente señalada. Con este fin analizaremos en los siguientes epígrafes los debates que sobre esta materia tuvieron lugar en aquella sede constituyente y los avatares de la participación política directa en los sucesivos trámites, desde el original anteproyecto hasta el texto final. La pretensión con que abordamos tal tarea no es tanto criticar el proceso constituyente o denunciar defectos del definitivo producto constitucional - que seguramente los hubo - cuanto encontrar razones y argumentos - si los hay que apoyen un cambio en el tratamiento constitucional de esta materia en el momento histórico actual.

\section{EL PROCESO CONSTITUYENTE ESPAÑOL EN EL CONTEXTO HISTÓRICO DE LA TRANSICIÓN POLÍTICA}

Suele utilizarse la expresión "transición democrática española" para designar el periodo histórico a lo largo del cual se materializó en nuestro país el cambio de régimen político, pasando de la dictadura franquista a una democracia homologable con las existentes en el entorno europeo de la época. El largo proceso constituyente, extendido en el tiempo desde junio de 1977 a diciembre de 1978, fue un elemento decisivo de esta transición democrática española, pero conviene evitar la identificación entre ambos conceptos. Aunque la cronología precisa de la transición española es cuestión controvertida, podemos aceptar que se inicia tras la muerte de Franco, en el momento en el que la sustitución de la dictadura se erige en el objeto central de la actividad política y los restantes intereses y estrategias, tanto de los grupos en el poder como de la oposición, se subordinan a la finalidad esencial de lograrla o evitarla, y que culmina con la 
aprobación de una Constitución normativa. Definido el nuevo orden, los objetivos politicos que adquieren prioridad ya no se relacionan con el cambio de régimen sino con la transformación del poder político de acuerdo a las orientaciones ideológicas de los distintos partidos.

Los procesos de transición democrática han sido caracterizados acertadamente como periodos de ambigüedad politica ${ }^{1}$ en los que se da una continua interacción entre elementos autoritarios y democráticos, entre orientaciones normativas, valores y prácticas heterogéneos entre sí. Como consecuencia, el tránsito desde el régimen autocrático al democrático se concreta en una sucesión de situaciones híbridas o intermedias en las que el primero va perdiendo progresivamente sus características y adquiriendo, correlativamente, las del segundo. Sin embargo, es insuficiente considerar la transición democrática como una mera etapa de post-autoritarismo o de pre-democracia, pues las circunstancias en que se desarrolla el proceso condicionan tanto el modo de liquidación del sistema político que desaparece como algunas características - perdurables en el tiempo - del modelo naciente. Esto se aprecia con singular claridad en el caso español.

Muchos aspectos de la transición española se ajustan y pueden ser explicados de modo convincente de acuerdo a las pautas de una transición pacífica mediante "traspaso" del poder, según la terminología de S. Huntington ${ }^{2}$. En el año 1975, a la muerte de Franco, las estructuras, las instituciones y las prácticas políticas típicas del franquismo resultaban anacrónicas - en la medida en que la modernización social y económica del país no había estado acompañada por una modernización política - y absolutamente disonantes en el contexto jurídico-político europeo del momento. La transformación del poder - en el sentido de Huntington - no era posible en esta situación, por lo que las alternativas, en cuanto a la dinámica de la transición a la democracia, se limitaban al reemplazo en el poder o al traspaso del mismo, conceptos que centraron el debate político de la época en forma de la dicotomía entre "reforma" o "ruptura". La debilidad del régimen se manifestaba sobre todo en el plano social, pero no tanto en el político o en el militar. La sensación de que el cambio democrático era inevitable no alcanzaba a ocultar la presencia de riesgos claros de conflicto y, aunque resultaba evidente que el franquismo no podria pervivir en el tiempo, el poder acumulado por su aparato era suficiente para asegurar una

1 César Cansino, Democratización y liberalización (Cuadernos de divulgación de la cultura democrática, núm. 14), Instituto Federal Electoral, México, 1997, pp. 13-15.

2 Cfr. Samuel Huntington, La tercera ola. La democratización a finales del siglo XX, Paidós, Buenos Aires, 1994, pp. 107 y ss. (capítulo 3, por título: “¿Cómo? Los procesos de democratización", especialmente apartado 1). Para explicar la dinámica de las transiciones pacíficas a la democracia, el autor define tres modelos básicos, en función de la correlación entre las fuerzas que detentan el poder no democrático y las fuerzas que aspiran a transformarlo en poder democrático. Cada proceso concreto se ajustaria a uno de ellos, aunque pueden constatarse situaciones intermedias. Así, Huntington habla de "transformación”, cuando las élites en el poder, aspirando a mantenerse en el mismo desde la legitimación democrática, dirigen y controlan el proceso de transición. Desde la lógica contraria, existe "reemplazo" en el poder cuando la oposición democrática tiene fuerza suficiente para imponer el cambio político conforme a sus condiciones, a las que tienen que someterse las élites que pierden el poder. Finalmente, el "traspaso" del poder es una situación intermedia: desde un relativo equilibrio de fuerzas, el resultado de una confrontación abierta resulta indefinido, por lo que tienden a predominar las posiciones moderadas que buscan pactar los tiempos y las condiciones del proceso de transición. 
resistencia fuerte si la oposición democrática intentaba forzar un final abrupto, con consecuencias impredecibles.

En el plano internacional, el Estado franquista había terminado por ser más o menos aceptado y mantenía relaciones comerciales, económicas y de cooperación con las potencias democráticas, con expectativas de integración en organismos supranacionales. En este contexto, un sector importante de las élites españolas se mostraba dispuesto a colaborar en la democratización del país, en tensión con otros sectores inmovilistas o integristas. El dificil equilibrio entre las fuerzas inmovilistas, reformistas y rupturistas hizo que las decisiones tomadas por todos los actores del proceso resolviesen paulatinamente la disyuntiva entre ruptura y reforma a favor de la segunda, por lo que no tiene mucho sentido elucubrar sobre qué pudo haber ocurrido en otro caso; pero sí resulta pertinente señalar qué rasgos derivados de dicho curso histórico proyectaron su influencia sobre el resultado del proceso, en lo político y en lo jurídico ${ }^{3}$. Desde el punto de vista jurídico, la dinámica de traspaso de poder se condensa y resume en la conocida expresión de T. Fernández-Miranda: "de la ley a la ley a través de la ley", verdadero principio rector del proceso español de transición a la democracia. La idea era utilizar los mecanismos previstos en el ordenamiento jurídico de la España franquista para promover las transformaciones necesarias de ese mismo ordenamiento hasta instaurar en el país una democracia equiparable a los estándares europeos. Utilizar la vía de la reforma para conseguir los objetivos de la ruptura, o, usando la expresión acuñada por J. Pérez Royo, llevar a efecto una "voladura controlada" del régimen 4 .

El proceso constituyente español de 1977-78 se inserta en este diseño de una evolución controlada desde el ordenamiento jurídico de partida hasta otro de llegada, antagónico con el anterior, y solo puede ser comprendido y valorado de este modo. Representa, dentro de dicho diseño, la específica etapa parlamentaria en la que se construyó el nuevo orden; pero antes y después se adoptaron decisiones trascendentes que influyeron directamente sobre el proceso constituyente o que trasladaron las abiertas prescripciones constitucionales al

\footnotetext{
3 Así, es un lugar común el afirmar que la transición "pactada” permitió ordenar el proceso y asegurar su inequívoco desenlace democrático, aunque nunca podremos saber qué hubiese acaecido en otro escenario más rupturista. Por otra parte, conllevó inevitables servidumbres: la forma de Estado, monarquía o república, fue extraída del debate, y hubo que pagar también un precio a las élites del franquismo que propiciaron el pacto por la democracia no solo en términos de mantenimiento de cierto estatus, sino también de impunidad y olvido histórico.

4 Javier Pérez Royo, Curso de Derecho Constitucional, Marcial Pons, Madrid, 2012, p. 91. La transición se desarrolló, por tanto, como un proceso planificado, no en los detalles pero sí en su trazo grueso. El objetivo era la democracia y el procedimiento para alcanzarla la reforma politica. Se necesitaba para ello el instrumento jurídico apropiado - la Ley para la Reforma Política - y la persona capaz de llevar la operación a buen puerto - Adolfo Suárez -. Pero, como señala M. Aragón, "en esas cuatro previsiones (objetivo del cambio, procedimiento general para llevarlo a cabo, instrumento jurídico particular para desencadenarlo, persona que dirigiría la marcha de la operación) puede decirse que se agotaba la planificación. Todo lo demás era por un lado, un conjunto de expectativas (...) bastante razonables (...); y, por otro, una tierra incógnita (el desarrollo pormenorizado del proyecto) que habria de conquistarse cada dia y donde las nuevas circunstancias e incluso el azar irrumpirian, muchas veces, en aquella escueta y vaga planificación". Manuel Aragón Reyes, "El camino hacia la Constitución: la articulación juridica de la transición”, en Manuel Aragón Reyes, Estudios de Derecho constitucional, CEC, Madrid, 1998, p. 23.
} 
espacio concreto de lo institucional ${ }^{5}$. De hecho, las decisiones fundamentales sobre la forma de Estado y la forma de gobierno - Estado democrático, autonomía territorial y monarquía parlamentaria - fueron tomadas en las fases previas al proceso constituyente, que en algún modo tuvo que partir de ellas. Las libertades politicas y los mecanismos de la democracia se habian hecho realidad, si bien de modo imperfecto, antes de la Constitución, lo que permitió que de las elecciones del 15 de junio de 1978 surgiese un parlamento de extracción democrática capaz de ejercer el poder constituyente con suficiente legitimidad. El instrumento jurídico esencial para conseguirlo fue la Ley para la Reforma Política, que se muestra así como el auténtico nexo de enlace entre las instituciones jurídicopoliticas del franquismo y las de una incipiente democracia: una norma ciertamente excepcional que, emanada de un poder no democrático, sentó las bases para la destrucción de dicho poder6.

La naturaleza original, heterodoxa si se quiere, del proceso constituyente español es evidente y deriva de esta conexión con el ordenamiento anterior. Las Cortes que llevaron a cabo el proceso no habían sido elegidas como constituyentes ${ }^{7}$, ni tampoco se habia producido una quiebra del poder político precedente con la subsiguiente instauración de un poder provisional encargado de dirigir y orientar el acontecer político hasta la vigencia de un texto constitucional. A ello habría que sumar un relativo desinterés de la ciudadanía, una ausencia de ese entusiasmo cívico que acompaña con frecuencia a la elaboración de una nueva Constitución. Sin embargo, que en aquella España de la transición se vivía un "momento constituyente" se nos muestra hoy como una realidad fuera de duda, pese a que en el debate jurídico de la época entremezclado de modo irremediable con el debate político - era cuestión discutida si lo que se desarrollaba en las Cortes era o no era un auténtico proceso constituyente ${ }^{8}$.

5 Richard Günther, "El proceso constituyente español", Revista de Estudios Políticos, núm. 49, 1986, p. 39.

${ }^{6}$ La Ley $1 / 1977$, de 4 de enero, para la Reforma Política fue la octava y última de las Leyes Fundamentales del Reino. Aprobada el 18 de noviembre de 1976 por las Cortes franquistas, con 435 votos a favor (sobre 531 procuradores), en lo que se ha considerado como un verdadero acto de "suicidio político", fue ratificada por el pueblo español en el referendo del 15 de diciembre, con una participación del 77 por 100 del censo electoral y un voto favorable del 94,17 por 100. Otras normas posteriores completaron su cometido democratizador. Merecen ser citados, en este sentido, cinco decretos leyes: a) RDL 12/1977, de 8 de febrero, sobre el derecho de asociación política (que permitió la legalización de todos los partidos políticos, incluida la del PCE, el 9 de abril de 1977, hito decisivo de la transición democrática), b) RDL 20/1977, de 18 de marzo, sobre normas electorales (en vigor hasta 1985 y cuyas lineas maestras fueron respetadas por la LOREG), c) RDL 17/1977, sobre relaciones de trabajo (que reconoció el derecho de huelga), d) RDL 24/1977, de 1 de abril, sobre libertad de expresión, y e) RDL 31/1977, de 2 de junio, sobre extinción de la sindicación obligatoria. También deben destacarse los instrumentos de ratificación de los tratados internacionales sobre derechos humanos, PIDCP y PIDESC, ambos de fecha de 13 de abril, por los que se integraron en el ordenamiento español.

7 El artículo 3 de la Ley 1/1977 atribuía al Gobierno y al Congreso la iniciativa para una "reforma constitucional", al tiempo que establecía el procedimiento parlamentario para tramitar la misma. Con ello, la Ley abría claramente la puerta a que una Cortes de extracción democrática art. 2 disposición transitoria primera Ley 1/1977 - acometiesen la tarea de elaborar una Constitución.

8 Una diversidad de posiciones que P. Lucas Verdú ejemplifica en las que mantuvieron por aquellas fechas los profesores C. Ollero Gómez, quien afirmaba el carácter constituyente de las 
Al respecto, son de interés las reflexiones tempranamente vertidas por $\mathrm{P}$. Lucas Verdú, quien, con el Anteproyecto de Constitución apenas concluido, atribuía un carácter singular y sui generis al proceso constituyente español, sobre todo porque arrancaba de una base jurídica fundamental, previa e impuesta - de un "pie forzado", usando la expresión del autor -, con merma para el poder constituyente de su calificación de originario y soberano, aunque sin negar su presencia y ejercicio. Lucas Verdú consideraba entonces adecuado hablar de "reformismo constituyente" o "heterogénesis" para designar un camino de producción del texto constitucional que, a pesar de la heterodoxia en cuanto a las causas y al curso del proceso, podía conducir a un resultado ortodoxo ${ }^{9}$. $\mathrm{O}$, dicho de otro modo, la existencia de un momento constituyente y la obtención, en último término, de un resultado constitucional bastarían para acreditar la naturaleza constituyente del proceso, con independencia de las consideraciones que pudiesen hacerse sobre la peculiar forma de manifestarse el poder constituyente en el caso español. Una opinión que esencialmente suscribimos, aunque se debe hacer notar que dicha peculiaridad, sin impedir la calificación del proceso como constituyente, lo condicionó sin duda, influenciando tanto su desarrollo como su producto final.

El procedimiento seguido para la elaboración del texto constitucional fue el marcado en el artículo 3 de la Ley 1/1977 para la reforma política en previsión de una posible "reforma constitucional", concretado en los reglamentos provisionales del Congreso y del Senado ${ }^{10}$. En la sesión del 27 de julio de 1977, el Congreso surgido de las elecciones de junio ejerció la iniciativa que al efecto le otorgaba el precepto citado, acordando la creación de una Comisión Constitucional, con una composición política que reflejaba la de la cámara, a la que se le encargó la redacción de un proyecto de Constitución. Constituida la comisión, esta nombró en su seno una ponencia de siete miembros que elaboraron un Anteproyecto de Constitución $^{11}$, punto de partida de una larga tramitación que incluía la

Cortes elegidas el 15 de junio de 1977, y J. Ferrando Badía, que lo negaba. Pablo Lucas Verdú, "La singularidad del proceso constituyente español", Revista de estudios políticos, núm. 1, 1978, pp. 11-12.

9 Pablo Lucas Verdú, "La singularidad del proceso constituyente español", op. cit., pp. 14-15: "Las discusiones sobre su ortodoxia me parecen inútiles siempre, claro está, que culmine su obra en una Constitución que obtenga suficiente consenso y sea duradera. Hoy no puede dudarse del carácter constituyente de las Cortes generales elegidas el 15 de junio de 1977”. Y más adelante, en la p. 15: "La irregularidad o heterodoxia del proceso constituyente español puede juzgarse según los resultados que alcance. Si lograse una finalidad positiva, o sea, el consenso sociopolítico español, la integración del pueblo en las instituciones contempladas en el texto constitucional, se habrian sanado las irregularidades, vicios o heterodoxias citados. (...) La génesis de la inminente Constitución ha sido heterodoxa; sus efectos, si logra consenso y duración, ortodoxos".

10 Reglamento provisional del Congreso de los Diputados, de 13 de octubre de 1977, y Reglamento provisional del Senado, de 14 de octubre de 1977.

11 Los integrantes de esta ponencia constitucional - a veces llamados los "padres de la Constitución" - fueron tres diputados de UCD (Miguel Herrero Rodríguez de Miñón, Gabriel Cisneros Laborda y José Pedro Pérez-Llorca y Rodrigo), uno del PSOE (Gregorio Peces-Barba Martínez), uno de Alianza Popular (Manuel Fraga Iribarne), uno del PCE (Jordi Solé Tura) y uno de la minoría catalana (Miquel Roca Junyent). La ponencia celebró veintinueve reuniones entre agosto y diciembre de 1977, de las que no hay versión oficial pues gozaron de carácter reservado. Las minutas y actas de las sesiones se publicaron en 1984 (Cfr. Actas de la Ponencia constitucional, Revista de las Cortes Generales, núm. 2., 1984, pp. 251-419). 
aprobación por el Congreso de un Proyecto de Constitución, la posibilidad de enmiendas en el Senado y la intervención de una Comisión Mixta CongresoSenado encargada de resolver las discrepancias. El texto final, antes de su sanción real, habría de ser ratificado por el pueblo en referendo.

\section{AVATARES DE LA PARTICIPACIÓN POLÍTICA DIRECTA A LO LARGO DEL ITER CONSTITUYENTE}

Cuando se comparan, en cuanto a la presencia de instrumentos de participación política directa, el anteproyecto redactado por los ponentes constitucionales y el texto aprobado definitivamente como Constitución española en diciembre de 1978, llama de inmediato la atención la profunda distancia existente entre ambos. Una comprensión cabal de la posición constitucional de las instituciones de participación política directa, su situación actual y sus posibilidades de desarrollo, no es posible sin un análisis explicativo de cuanto ocurrió con ellas en el largo trayecto constituyente ${ }^{12}$, que tendremos que basar en el estudio de la evolución del texto articulado, de los debates constituyentes que la acompañaron y de las circunstancias que rodearon el proceso.

\subsection{Los instrumentos de participación politica directa en el Anteproyecto de Constitución}

El anteproyecto ${ }^{13}$ redactado por la ponencia constitucional realizó una acogida razonablemente generosa de los instrumentos para la participación politica directa, lo que resultaba coherente con la definición del Estado como democrático, con la afirmación de la soberanía popular y con la garantía constitucional de la misma como vertiente del derecho fundamental de los ciudadanos a la participación política. Enlazando en cierta medida con la Constitución republicana de 1931, se contemplaron en este texto tanto la iniciativa legislativa popular como el referendo legislativo, al tiempo que se recuperaba la iniciativa popular para la reforma constitucional, eliminada en el último momento por las constituyentes republicanas. A estas figuras se sumaron otras más modernas, como el referendo sobre decisiones políticas de especial trascendencia y el referendo abrogativo, completándose el cuadro con otros referendos conectados con los procedimientos para el acceso a la autonomía territorial o con la ratificación popular de las reformas constitucionales.

\footnotetext{
12 Aunque son usuales las alusiones a determinados episodios del proceso constituyente en relación con la participación política directa, al papel de determinados actores constituyentes o a intervenciones concretas, no abundan los estudios sistemáticos de la cuestión. Es cita obligada, en este sentido la de Alfredo Ramirez Nardiz, "El debate en torno a los mecanismos de democracia participativa durante el proceso constituyente español", Cuadernos Constitucionales de la Cátedra Fadrique Furió Ceriol, núm. 67-68, 2009, pp. 167-178. También se ha ocupado de estas cuestiones, aunque no con carácter monográfico, M. A. Presno. Cfr. Miguel Ángel Presno Linera, "La participación ciudadana en el procedimiento legislativo como parte de la esencia y valor de la democracia", Asamblea, núm. 27, 2012, pp. 85-119, especialmente los apartados III y V, donde el autor ofrece una excelente revisión de las intervenciones producidas en los debates constituyentes en torno a la iniciativa legislativa popular y al referendo.
}

13 Boletín Oficial de las Cortes, núm. 44, de 5 de enero de 1978, que recoge tanto el texto articulado del anteproyecto como los votos particulares al mismo. 
La ponencia decidió incluir la iniciativa legislativa popular en el art. 80 del anteproyecto, como apartado cuarto de este precepto ${ }^{14}$, en el que se regulaba la iniciativa legislativa, debido a la insistencia del representante de Alianza Popular, M. Fraga Iribarne, quien llegó a anunciar un voto particular discrepante cuando, en una primera lectura, esta institución se había dejado fuera ${ }^{15}$. En comparación con el precedente histórico de 1931, se redujo sustancialmente el requisito de apoyo popular, fijado ahora en "las firmas acreditadas de quinientos mil electores", al tiempo que se introducía una moderada limitación constitucional al ámbito material de la institución, estableciéndose su improcedencia "en materia tributaria, de carácter internacional" y "en lo relativo a la prerrogativa de gracia". La incorporación de la iniciativa legislativa popular dentro del artículo 80 del anteproyecto llevaba aparejada la de la iniciativa popular para la reforma constitucional, en virtud de la remisión a los términos del artículo 80 hecha por el artículo 157 del anteproyecto ${ }^{16}$. Por otra parte, en el artículo $85^{17}$ se recogían tres modalidades de referendo popular, para "la aprobación de las leyes votadas por las Cortes Generales y aún no sancionadas, las decisiones politicas de especial trascendencia y la derogación de leyes en vigor", todos ellos con carácter vinculante, correspondiendo la convocatoria al Rey, "a propuesta del Gobierno, a iniciativa de cualquiera de las Cámaras, o de tres asambleas de Territorios Autónomos". Además, se contemplaba la iniciativa popular para la convocatoria del referendo abrogativo, siendo necesario para su ejercicio el respaldo de setecientos cincuenta mil electores. Del juego conjunto de estos preceptos resultaba un cierto equilibrio entre los mecanismos de la democracia parlamentaria y representativa, base indiscutible del sistema político, y los de participación política directa, que hubiese contribuido probablemente, de haberse consolidado en el texto constitucional, a afinar la sintonía entre las decisiones politicas y la voluntad popular.

Los representantes de los grupos socialista y comunista formularon sendos votos particulares ${ }^{18}$ a la redacción propuesta por la ponencia para el artículo 85 del anteproyecto. En el primero de ellos, G. Peces-Barba proponía la extensión de la iniciativa popular a las tres modalidades de referendo, rebajando el requisito de

14 Art. 80.4 Anteproyecto CE: "Podrán someterse al Congreso proposiciones de ley articuladas y motivadas, con las firmas acreditadas de quinientos mil electores. La iniciativa popular no procede en materia tributaria, de carácter internacional, ni en lo relativo a la prerrogativa de gracia. La ley regulará el ejercicio de este derecho".

15 Actas de la Ponencia constitucional, op. cit., pp. 290-291.

16 Art. 157 Anteproyecto CE: "La iniciativa de reforma constitucional se ejercerá en los términos del artículo ochenta".

17 Art. 85 Anteproyecto CE: "1. La aprobación de las leyes votadas por las Cortes Generales y aún no sancionadas, las decisiones políticas de especial trascendencia y la derogación de leyes en vigor, podrán ser sometidas a referéndum de todos los ciudadanos. 2. En los dos primeros supuestos del número anterior el referéndum será convocado por el Rey, a propuesta del Gobierno, a iniciativa de cualquiera de las Cámaras, o de tres asambleas de Territorios Autónomos. En el tercer supuesto, la iniciativa podrá proceder también de setecientos cincuenta mil electores. 3. El plazo previsto en el artículo anterior, para la sanción real, se contará, en este supuesto, a partir de la publicación oficial del resultado del referéndum. 4. El resultado del referéndum se impone a todos los ciudadanos y a todos los órganos del Estado. 5. Una ley orgánica regulará las condiciones del referéndum legislativo y del constitucional, así como la iniciativa popular a que se refiere el presente artículo y la establecida en el artículo 80".

18 Boletín Oficial de las Cortes, núm. 44, de 5 de enero de 1978, pp. 705 y 718. 
apoyo ciudadano a quinientos mil electores. A cambio, se eliminaba el carácter necesariamente vinculante del referendo, remitiendo la determinación de sus efectos a la regulación legal. El voto particular de J. Solé Tura, por su parte, planteaba como único cambio suprimir la iniciativa popular para el referendo abrogativo. Aunque los ponentes de UCD no emitieron voto particular alguno, es claro que tenian prevenciones ante la iniciativa popular. Así lo indica el hecho de que la iniciativa legislativa popular fuese desechada en una primera fase de los trabajos de la ponencia, aunque después fue aceptada; y también que el grupo de UCD propusiese de nuevo su eliminación, junto con la de la iniciativa popular para el referendo, en el trámite de enmiendas. Existian, como vemos, diferentes posiciones de partida en cuanto a la constitucionalización de los institutos de participación política directa. Pero la naturaleza y magnitud de las mismas no permitía predecir, desde luego, el giro radical que iba a tener lugar en las siguientes etapas del proceso constituyente.

El referendo constitucional fue recogido en el artículo 158 del Anteproyecto de Constitución, como colofón de un rígido procedimiento de reforma, con carácter obligatorio y vinculante. En este punto se separaba claramente la ponencia de la Constitución de 1931, que articuló un procedimiento igualmente rígido pero sin ratificación popular directa, al tiempo que se mostraba consecuente con el hecho de que el propio texto constitucional que se estaba elaborando necesitaba ser aprobado en última instancia por el pueblo español ${ }^{19}$. El único voto particular a este artículo fue uno de M. Fraga en el que planteaba dos procedimientos de diferente rigidez en función del alcance de la reforma constitucional - en la línea de la regulación que finalmente prevaleció -, aunque manteniendo para ambos la necesaria ratificación final por medio de un referendo.

En cuanto a las consultas de ámbito territorial vinculadas al proceso autonómico, el artículo $131 \mathrm{del}$ anteproyecto incorporaba un referendo obligatorio y vinculante para la aprobación de los estatutos, que podría celebrarse con carácter previo a su ratificación por las Cortes, de haber acuerdo entre la asamblea de parlamentarios redactora del proyecto de estatuto y la Comisión Constitucional del Congreso, o como punto final del proceso cuando el proyecto de estatuto fuese tramitado como proyecto de ley por las Cortes, ante la falta de dicho acuerdo. El artículo 132.2 establecía para la reforma de los estatutos un procedimiento análogo al de su elaboración, con un referendo obligatorio, en los mismos términos del artículo 131, para la aprobación de la reforma estatutaria. La configuración y función de estos instrumentos participativos conectaba directamente con el diseño de los procesos estatuyentes y de reforma estatutaria,

19 Desde el Estatuto de Bayona hasta la Constitución republicana de 1931, ninguna ley fundamental española había contemplado la necesidad de ratificación popular de su reforma o revisión. Sin embargo, el régimen franquista sí incorporó esta figura para la modificación de las pseudoconstitucionales leyes fundamentales, en un intento de legitimarse tanto interna como externamente. Así, el artículo 10 de la Ley de Sucesión en la Jefatura del Estado, de 26 de julio de 1947, establecía que para derogar o modificar las leyes fundamentales "será necesario, además del acuerdo de las Cortes, el referéndum de la Nación". Y también la Ley para la reforma política, en su artículo 3.3: "El Rey, antes de sancionar una Ley de Reforma Constitucional, deberá someter el Proyecto a referéndum de la Nación", precepto del que surgía, precisamente, la obligatoriedad de someter a consulta popular el resultado final del proceso constituyente en curso. Cfr. Joan Oliver Araujo, "El referéndum en el sistema constitucional español", Cuadernos de la Facultad de Derecho, núm. 15, Universidad de Palma de Mallorca, 1986. 
por lo que su evolución a lo largo del iter constituyente no siguió la misma lógica que la de los restantes mecanismos de participación política directa, y estuvo condicionada, sobre todo, por los sucesivos cambios en relación con la concepción y articulación del Estado autonómico. A realizar un breve análisis de esta evolución dedicamos el siguiente epígrafe.

\subsection{Los referendos de ámbito territorial en el debate constituyente sobre el modelo territorial del Estado}

El modelo para la descentralización territorial del poder político incorporado por el anteproyecto entroncaba claramente con el precedente de la Segunda República española - plasmado en el Título I de la Constitución de 1931 - y partía, como este, del principio de voluntariedad regional, con renuncia a la constitucionalización de un concreto mapa autonómico. La ponencia llevó a cabo su labor a partir de un texto presentado por el representante de la minoría catalana, M. Roca ${ }^{20}$, que ha sido calificado como "claro, coherente y bastante autonomista" 21 . Los rasgos esenciales del modelo propuesto eran la iniciativa municipal, una misma vía jurídica para el acceso a la autonomía de todos los territorios que iniciasen el proceso, un único modo de establecer las competencias autonómicas - por atribución estatutaria con respeto de las competencias exclusivas del Estado constitucionalmente fijadas -, un procedimiento paritario de elaboración del estatuto - con intervención de una asamblea ad hoc de diputados y senadores del territorio y de las Cortes - con referendo final de ratificación, un procedimiento análogo para la modificación estatutaria y una organización institucional igualmente única, integrada por una asamblea y un Consejo de Gobierno encabezado por el Presidente de la comunidad autónoma ${ }^{22}$.

La inclusión del referendo de aprobación del Estatuto encajaba en este marco como un elemento clave para la legitimación democrática de la autonomía y no tanto como mecanismo de comprobación de una inequivoca "voluntad regional" de autogobierno, a diferencia de los plebiscitos territoriales previstos en la Constitución de $1931^{23}$. Esta distinta concepción conllevaba dos remarcables diferencias: una exigencia de respaldo popular mucho más baja que la contenida en el art. 12 CE 1931 - la mayoría de los votos válidamente emitidos frente a los dos tercios del censo electoral - y un cambio en el objeto del pronunciamiento ciudadano, que ya no era un estatuto elaborado desde el territorio sino coelaborado por la asamblea y las Cortes, jugando estas, ahora, un papel mucho más activo y decisorio.

20 Actas de la Ponencia constitucional, op. cit., pp. 322 y ss. (minuta correspondiente a la sesión del 15 de noviembre de 1977).

21 Agustín Ruiz Robledo, "Veinticinco años de Estado autonómico", Revista de Derecho Político, núms. 58-59, 2003-2004, p. 713.

22 Cfr., especialmente, los artículos del anteproyecto 129 (iniciativa autonómica), 137 y 138 (competencias estatales y autonómicas), 131 (elaboración del Estatuto) y 132 (reforma del Estatuto y organización institucional básica)

23 Jorge de Esteban Alonso, Luis López Guerra et al., El régimen constitucional español (Vol. I), Labor Universitaria, Barcelona, 1980, p. 97. Se pretende, sobre todo, es dar fundamento democrático "a una decisión de tanta trascendencia como es la que toca al proceso autonómico, base de la descentralización del Estado". 
Sin embargo, el diseño constitucional del Estado autonómico plasmado en el anteproyecto fue demolido en el trámite de comisión y no precisamente como consecuencia de las enmiendas presentadas, que fueron muchas y de variopinto cuño ${ }^{24}$, sino por un giro en la posición de la ponencia, que cambió drásticamente su criterio y reescribió por propia iniciativa y por completo el Título VIII tomando como base un documento aportado por UCD que no había sido tramitado como enmienda, lo que motivó la protesta de los ponentes G. Peces-Barba, J. Solé Tura y M. Roca ${ }^{25}$. En el informe de la ponencia aparecía articulado ${ }^{26}$, por vez primera, un nuevo modelo que, a diferencia del anteproyecto, venía a establecer tres regímenes distintos en cuanto al acceso y al alcance de la autonomia: a) un régimen general, con una iniciativa menos exigente en sus requisitos de ejercicio y con un procedimiento de elaboración del estatuto más sencillo y sin referendo popular, que permitía acceder de inmediato a unas competencias limitadas que, pasados cinco años, podían aumentar hasta un techo máximo, marcado por las competencias exclusivas del Estado, por medio de reforma estatutaria; b) un régimen especial, que hacía posible acceder de inmediato al techo máximo competencial, pero imponiendo a cambio una iniciativa mucho más exigente, con referendo de iniciativa autonómica incluido, un procedimiento de elaboración estatutaria más complejo y referendo obligatorio de ratificación; y c) una tercera via, prevista para los territorios que habian plebiscitado afirmativamente durante la Segunda República su autonomía - es decir, Cataluña, País Vasco y Galicia -, que suponía su acceso inmediato a la autonomía plena, debiéndose elaborar el estatuto de autonomía por el procedimiento establecido para las comunidades de régimen especial. En esta propuesta incorporada al informe de la ponencia se descubren ya los principales rasgos del esquema territorial del Estado que a la postre sería constitucionalizado, cuya particularidad más notoria es una manifiesta ambigüedad en cuanto al desarrollo futuro del mismo. Su contenido, al margen de los cambios de numeración, ordenación y ubicación sistemática de los preceptos solo experimentó ligeras modificaciones en el resto del iter constituyente.

Aunque a veces se ha considerado que esta fórmula fue el resultado de un pacto entre los defensores de concepciones federalistas más ortodoxas, los partidarios de un Estado unitario descentralizado y los nacionalistas periféricos que centraban sus esfuerzos en lograr las mayores cotas de autogobierno para su propio territorio, no nos parece que sea esta la interpretación más adecuada. Más bien, el modelo que introdujo la ponencia contra su primer criterio - y que

${ }^{24}$ Las Enmiendas del Congreso al Anteproyecto de Constitución no se publicaron en el Boletín Oficial de las Cortes sino en un documento separado. Pueden consultarse en http://www.congreso.es/constitucion/ficheros/enmiendas/enmcongreso.pdf [consultado: 1-122016]. En relación con el modelo territorial del Estado fueron muy numerosas e "iban en todas las direcciones imaginables, desde las preocupadas por resaltar la unidad de España - que se consideraba en peligro al haber recogido en el artículo dos el término 'nacionalidades'- hasta las movidas por el deseo de proclamar una confederación". Agustín Ruiz Robledo, "Veinticinco años de Estado autonómico", op. cit., p. 713.

${ }^{25}$ Actas de la Ponencia constitucional, op. cit., pp. 339 (queja de G. Peces-Barba) y 342 (posición de J. Solé Tura y M. Roca a favor de trabajar sobre el texto original y voto en contra de tomar como punto de partida el nuevo texto aportado por UCD).

26 Boletin Oficial de las Cortes, núm. 82, de 17 de abril de 1978. El cambio en el diseño del proceso autonómico que realiza el informe se expresa en una redacción ex novo del Título VIII y en el añadido de una disposición adicional. 
perduró en el texto constitucional - representaba una forma de entender la descentralización del Estado que, recelosa ante eventuales tensiones centrifugas, intentó limitarlas mediante una estrategia doble: favorecer, por un lado, lo inevitable - la adquisición por parte de las nacionalidades históricas de cotas altas de autogobierno - y, por otro, facilitar al máximo el acceso del resto de las regiones a una autonomía limitada. Respondía, por tanto, a una idea dual del Estado autonómico - desmentida más adelante por la evolución histórica de este - en la que se pensaba que la evolución del mismo, conforme a los patrones establecidos, desembocaría probablemente en la futura coexistencia de dos tipos de comunidades autónomas: unas dotadas de autonomía política plena y de órganos legislativos propios y otras, la mayoria, con una elevada autonomía administrativa pero sin capacidad legislativa ${ }^{27}$. El principal factor que propició el surgimiento y éxito de la propuesta fue, sin duda, la imposición en el seno del Gobierno de las tesis de J. Clavero Arévalo, ministro para las regiones, lo que condujo a la extensión de las preautonomías a lo largo y ancho del Estado español entre enero y octubre de 1978, en paralelo a un proceso constituyente sobre el que este dato fáctico ejerció, sin duda, una gran influencia, condicionando y modulando las posiciones de todos los actores ${ }^{28}$.

En lo que a nosotros más nos interesa, la posición de los referendos territoriales en este nuevo escenario quedó fijada desde su irrupción en el informe de la ponencia, supeditada a los objetivos que se perseguían, y, en lo fundamental, ya no variaría en lo sucesivo. Como la intención - nunca declarada claramente - era que la mayoría de las regiones optasen por el régimen general, se prescindió dentro de este, para facilitarlo, de cualquier tipo de consulta directa al pueblo; así, bastaba con el impulso del órgano preautonómico, el acuerdo de dos tercios de los ayuntamientos y la elaboración después por una asamblea ad hoc de un proyecto de estatuto que sería tramitado como ley orgánica por las Cortes. La renuncia a una fundamentación democrática directa refuerza, qué duda cabe, la idea de que esta vía de acceso se pensó para abrir paso a una descentralización administrativa muy importante pero limitada en los aspectos políticos. Y, en la medida en que se pretendía que el acceso al régimen especial fuera de los supuestos de Cataluña, País Vasco y Galicia - fuese en todo caso excepcional, se estableció un procedimiento agravado para la iniciativa autonómica con el principal escollo, de muy difícil superación, de un referendo que requería el voto afirmativo de la mayoría absoluta de los electores en todas las provincias; lo que no se justifica desde el punto de vista de una mayor legitimidad democrática, en nuestra opinión, sino desde la voluntad de interponer

27 Sobre la concepción dual de la autonomía como idea implícita en el diseño del proceso autonómico al que abrió paso el informe de la Ponencia constitucional de abril de 1978 , cfr. Agustín Ruiz Robledo, "Veinticinco años de Estado autonómico", op. cit., pp. 715 y ss. El autor aduce a favor de esta tesis la lectura de los debates constituyentes y las opiniones de participantes como J. Clavero o E. Attard, junto con la pura interpretación técnica que le lleva a formular la siguiente pregunta retórica: “¿tiene la mínima lógica establecer un referéndum de ratificación autonómica con un quórum dificilisimo de alcanzar para llegar cinco años antes al punto al que acabarán llegando todas las demás?”.

28 Así, el desarrollo del proceso preautonómico fue cronológicamente paralelo al proceso constituyente y contribuyó a que el modelo autonómico que sustituyó al consenso inicial de la Ponencia fuese aceptado. 
un obstáculo de carácter casi disuasorio ${ }^{29}$. La traba fundamental se insertó, pues, en relación con el ejercicio de la iniciativa autonómica y no con la elaboración posterior del estatuto de autonomía, el cual también debía ser objeto de un referendo final en el que eran necesarios, para su aprobación, la mayoría absoluta de los votos emitidos. Un requisito que fue agravado en el trámite seguido por el proyecto en la Comisión Constitucional del Senado, donde dicha mayoria pasó a ser exigible en todas las provincias del territorio aspirante a la autonomía.

El mapa de la participación política directa dentro del diseño del proceso autonómico se completó, por último, con un referendo obligatorio para la reforma de los estatutos elaborados conforme al régimen especial, introducido en el dictamen de la Comisión de Asuntos Constitucionales y Libertades Públicas del Congreso, y con la previsión de un referendo popular en el caso de que el órgano foral competente instase la adhesión de Navarra al régimen autonómico vasco ${ }^{30}$.

\subsection{Desmantelamiento del programa participativo de la ponencia por la Comisión de Asuntos Constitucionales y Libertades Públicas}

Ni los votos particulares de algunos miembros de la ponencia constitucional en relación con los artículos 80.4 y 85 del Anteproyecto de Constitución - a los que ya nos hemos referido - ni las enmiendas formuladas a dichos preceptos suponían una impugnación global del diseño que, en cuanto a la participación política directa de los ciudadanos, había resultado de los trabajos de la ponencia. De entre todas, llama la atención la doble enmienda del grupo de UCD en la que planteó la eliminación tanto de la iniciativa legislativa popular como de la iniciativa popular para el referendo ${ }^{31}$. Los grupos de la izquierda propusieron asimismo restricciones en sus enmiendas, no siempre coherentes con los votos particulares precedentes de sus ponentes constitucionales ${ }^{32}$, lo que revela una

29 En contra Alberto Oliet Palá, "El principio politico formal de identidad en el ordenamiento constitucional español", Revista de derecho político, núm. 24, 1987, p. 106, para quien "la inclusión del referéndum de iniciativa autonómica fue una victoria de la participación directa en el debate constituyente"..

30 Previsión incorporada como disposición transitoria tercera en el informe de la ponencia tras la admisión de una enmienda de consenso (núm. 778), firmada por los grupos parlamentarios de UCD, socialista y nacionalista vasco. La redacción de esta disposición permaneció inalterada hasta el final del proceso constituyente, salvo en su numeración - finalmente disposición transitoria cuarta CE -. Enmiendas del Congreso al Anteproyecto de Constitución, op. cit., p. 362363.

31 Enmienda núm. 779, firmada por Unión de Centro Democrático, en la que plantea modificaciones a diversos artículos del anteproyecto y, entre ellos, a los arts. 80.4 y 85. La justificación para suprimir todo vestigio de iniciativa popular en el texto es significativa: "La soberanía reside en el pueblo español y se ejerce en un régimen parlamentario a través de los órganos del Estado que la propia Constitución determina. La apelación directa al pueblo queda garantizada por la institución del referéndum que se recoge en la presente Constitución". Enmiendas del Congreso al Anteproyecto de Constitución, op. cit., pp. 375 (al art. 80.4) y 375-376 (al art. 85).

32 Así, el grupo socialista pretendía ahora situar fuera del alcance del referendo abrogativo las leyes orgánicas, mientras que el grupo comunista sugería dejar este referendo abrogativo como única modalidad, reduciendo el requisito para la iniciativa popular del mismo a quinientos mil electores. Una enmienda esta contradictoria con el voto particular de J. Solé Tura en el que se mantenían todas las modalidades de referendo pero suprimiendo la iniciativa popular para el 
posición hasta cierto punto indefinida y oscilante de los partidos de izquierda en los primeros compases del procesos constituyente ante la participación política directa, posición que se iria decantando a lo largo de los trabajos parlamentarios hacia una clara desconfianza. Por lo que toca al grupo de Alianza Popular, la enmienda más significativa proponía eliminar las limitaciones materiales a la iniciativa legislativa popular ${ }^{33}$.

En el informe de la ponencia no se registraron grandes modificaciones, siendo rechazadas la mayor parte de las anteriores enmiendas. No obstante, se le dio una redacción distinta al artículo 85 que regulaba el referendo, en la que destacan dos cambios sustantivos respecto al texto anterior. El primero, en la línea del voto particular de G. Peces-Barba, fue la supresión del carácter necesariamente vinculante del referendo, remitiendo a la regulación legal la concreción de sus efectos. Por mor del segundo, se reducía la capacidad de iniciativa de las asambleas autonómicas al estricto ámbito del referendo abrogativo. El artículo 80.4, referido a la iniciativa legislativa popular, no sufrió modificaciones, pasando a dictamen de la Comisión de Asuntos Constitucionales y Libertades Públicas en los mismos términos del Anteproyecto. Nada hacía presagiar, por tanto, la drástica revisión que en materia de participación política directa iba a aplicar la comisión sobre el programa consensuado por la ponencia.

La aprobación por unanimidad de una enmienda in voce del diputado $\mathrm{O}$. Alzaga, de UCD, relativa a la iniciativa legislativa popular, fue el primer episodio a la vez que el más leve - de una serie de recortes en que dicha revisión se materializó de modo progresivo. Con ella, se aceptaba retirar la enmienda de supresión del artículo 80.4 del anteproyecto solicitando, a cambio, la inclusión de cautelas adicionales: remisión a una futura ley orgánica de "las formas de ejercicio y los requisitos" de esta figura participativa y apertura a que tal ley pudiese exigir un apoyo mínimo de la iniciativa superior a las quinientas mil firmas, al contemplarse esta cifra no como un requisito determinado constitucionalmente sino como un limite inferior del requisito ${ }^{34}$.

La actividad revisoria de la comisión se proyectó especialmente sobre el contenido del artículo 85 del anteproyecto - artículo 86 en el dictamen de la comisión -, como resultado de una enmienda, también in voce, del diputado comunista J. Solé Tura, que fue aceptada rápidamente por la mayor parte de los

mismo. Respectivamente, enmiendas núm. 416, firmada por Grupo Socialista del Congreso, y núm. 703, firmada por T. García García (Grupo Comunista del Congreso). Enmiendas del Congreso al Anteproyecto de Constitución, op. cit., p. 184 y pp. 317-318.

33 Enmienda núm. 2, firmada por A. Carro Martínez (Grupo de Alianza Popular Enmiendas del Congreso al Anteproyecto de Constitución, op. cit., p. 8.

${ }^{34}$ Artículo 81.4 del dictamen de la Comisión de Asuntos Constitucionales y Libertades Públicas del Congreso: "Una ley orgánica regulará las formas de ejercicio y requisitos de la iniciativa popular para la presentación de proposiciones de ley. En todo caso se exigirán no menos de 500.000 firmas acreditadas y no procederá en materia tributaria o de carácter internacional, ni en lo relativo a la prerrogativa de gracia”. Hay que recordar aquí que el grupo de UCD sentía una gran desconfianza hacia esta forma de participación - cuya eliminación habia propuesto -, como se refleja en las palabras de O. Alzaga defendiendo su enmienda in voce: "una figura de este género que, repetimos, está poco acuñada y experimentada en la práctica del Derecho comparado, va a requerir una regulación meditada en la Ley Orgánica pertinente y a tal efecto nos pronunciamos en nuestra enmienda (...)". 
grupos parlamentarios ${ }^{35}$. Su efecto puede ser descrito como una demolición completa de la arquitectura constitucional del referendo que proponía este precepto, con la desaparición tanto del legislativo como del derogatorio y, con este, de todo vestigio de iniciativa popular para la convocatoria; fue igualmente suprimida la iniciativa de las asambleas autonómicas. En la nueva redacción solo permanecía, pues, el referendo sobre decisiones politicas de especial trascendencia, aunque con un nuevo carácter meramente consultivo, correspondiendo la iniciativa de su convocatoria al Presidente del Gobierno previa aprobación del Congreso ${ }^{36}$.

La enmienda del representante comunista resulta, atendiendo a las circunstancias en que se produjo, sorprendente. No solo es obvio que no trataba "de alcanzar un acuerdo entre los distintos criterios expuestos" - condición de admisibilidad de la enmienda in voce conforme al Reglamento Provisional del Congreso $^{37}$-, sino que iba más allá, en su intencionalidad restrictiva, del voto particular del propio J. Solé Tura al anteproyecto y, por otra parte, era contradictoria con la enmienda de su grupo en la que se pedía la eliminación del referendo sobre decisiones politicas de especial trascendencia - tanto el voto particular como la enmienda fueron retirados verbalmente por Solé Tura en el inicio de su intervención -. También sorprende la facilidad con que una propuesta tan sustancial obtuvo el respaldo de otros grupos. En realidad, todo apunta a que fue fruto de un acuerdo previo entre partidos alcanzado en sede extraparlamentaria ${ }^{38}$, aunque no son claras las razones por las que se decidió, en aquel preciso momento y de forma inopinada, reducir la presencia constitucional del referendo a la mínima expresión posible.

Es muy probable que la inminencia de la celebración de dos referendos abrogativos en Italia - la sesión de la comisión donde se modificó drásticamente el artículo 85 del anteproyecto se celebró el 6 de junio de 1978, y los referendos italianos estaban convocados para el 11 de junio - influyese de modo importante en el ánimo de los diputados de unos partidos que no eran especialmente proclives a la democracia directa. El desarrollo de la campaña de estos referendos en los primeros días de junio, la polémica sentencia de la Corte Constitucional

35 Si bien M. Fraga Iribarne y H. Barrera votaron en contra. Diario de Sesiones del Congreso de los Diputados, núm. 81, de 6 de junio de 1978, pp. 2937-2938.

36 Artículo 86 del dictamen de la Comisión: “1. Las decisiones políticas de especial trascendencia podrán ser sometidas a referéndum consultivo de todos los ciudadanos. 2 . E1 referéndum será convocado por el Rey con refrendo del Presidente del Gobierno y previo debate del Congreso de los Diputados. 3. Una ley orgánica regulará las condiciones y el procedimiento de las distintas modalidades de referéndum previstas en esta Constitución". Aunque la definición de la iniciativa no es la mejor posible, está claro que su sentido es coincidente con el de la redacción definitiva del art. $92 \mathrm{CE}$ : propuesta del Presidente del Gobierno y autorización previa del Congreso.

37 Artículo 119 del Reglamento Provisional del Congreso de los Diputados, de 13 de octubre de 1977.

38 Según O. Alzaga, uno de los protagonistas del debate en la Comisión, “(...) se elaboró un enmienda in voce, consensuada por la casi totalidad de los Grupos Parlamentarios, pero que no gozó del respaldo de Alianza Popular". Los términos de esta referencia parecen confirmar la idea de que la enmienda defendida por Solé Tura había sido consensuada previamente. Óscar Alzaga Villaamil, Comentario sistemático a la Constitución española de 1978, Editorial del Foro, Madrid, 1978 , p. 581. 
italiana en la que se declararon constitucionalmente inadmisibles cuatro de los ocho consultas propuestas por el Partido Radical ${ }^{39}$, la utilización que de este instrumento comenzaba a hacer, por aquella época, este partido en Italia ${ }^{40} \mathrm{y}$, sobre todo, el hecho de que uno de los referendos italianos proponía derogar la ley de contribución del Estado a la financiación de los partidos políticos, fueron factores que pesaron, seguramente, en la decisión adoptada ${ }^{41}$. El resultado de esta votación en Italia, con una participación superior al 80 por 100 y con un peligroso 43,6 por 100 de los votantes inclinados a acabar con la financiación pública de los partidos políticos, confirmaron a los partidos españoles, seguramente, en sus temores y aprensiones ante la inserción de ciertas formas de referendo popular facultativo y vinculante en el procedimiento legislativo y, en general, ante las instituciones de participación politica directa, lo que hacía muy difícil una recuperación, siquiera parcial, del texto de la ponencia en algún momento posterior.

La enmienda de J. Solé Tura dio lugar a un intenso debate en el seno de la comisión del que da cuenta el Diario de Sesiones del Congreso ${ }^{42}$, en el que los argumentos se centraron en los hipotéticos riesgos que comportarian para la democracia parlamentaria, de ser aceptados, los tipos de referendo previstos en el anteproyecto, mientras que las alusiones a los referendos italianos fueron solamente tangenciales. Solé Tura, por ejemplo, señalaba que el referendo sobre leyes aprobadas por las Cortes pero no sancionadas abría "una extraña posibilidad de que la soberanía del Parlamento sea absolutamente menoscabada y establece, sobre todo, la posibilidad de conflictos muy serios entre Gobierno, Rey y Parlamento", mientras que la consulta sobre decisiones políticas de especial trascendencia, de ser vinculante, "puede dar lugar también a que el Parlamento quede absolutamente colocado en un segundo plano". En cuanto al referendo abrogativo, este "se presta, como sabemos, a muchas y contradictorias

39 SCC 16/1978, de 7 de febrero.

40 Durante años, el referendo fue un elemento central de la estrategia del Partido Radical, que lo usó como auténtica plataforma política alternativa. Cfr. Cesáreo Rodríguez-Aguilera, "Los efectos del referéndum abrogativo en el sistema político italiano", Revista de estudios políticos, núm. 59, 1988. También Massimo Luciani, "El referéndum. Cuestiones teóricas y de la experiencia italiana", Revista catalana de dret públic, núm. 37, 2008., p. 14: "En el año 1977, los radicales recogieron muchas firmas en apoyo de un gran número de peticiones de referéndum, que tenían por objetivo abrogar leyes en las materias más diversas (...) El objetivo político de los radicales era claro: hacer más dificil el diálogo entre DC y PCI; abrir dentro de la mayoría y de la oposición fuertes contradicciones, crearse un espacio político más amplio (...). Trasladando el terreno de la confrontación de la sede parlamentaria a las plazas y a las urnas referendarias, en definitiva, se trataba de reabrir a favor suyo un juego que, de otra manera, se habría cerrado irremediablemente".

41 La simultaneidad en el tiempo del proceso referendario italiano con la discusión en la Comisión del artículo que debía regular constitucionalmente el referendo español ha sido destacada por Pedro Cruz Villalón, "El referéndum consultivo como modelo de racionalización constitucional", en Revista de estudios politicos, núm. 13, 1980, pp. 151-152. También se refieren a ella Alberto Oliet Palá, "El principio politico formal de identidad en el ordenamiento constitucional español", op. cit., p. 120, y Miguel Ángel Presno Linera, "La participación ciudadana en el procedimiento legislativo como parte de la esencia y valor de la democracia”, op. cit., p. 93.

42 Diario de Sesiones del Congreso de los Diputados, núm. 81, de 6 de junio de 1978, pp. 29372946. En estas páginas se transcriben los debates de la comisión en torno a la enmienda formulada in voce por J. Solé Tura. Todas las citas textuales que se entrecomillan en este párrafo están entresacadas de ellas. 
utilizaciones", siendo "dudoso que se pueda calificar, sin más, de práctica democrática", y la iniciativa popular para el mismo sería innecesaria en la medida en que ya "quedaba prevista la posibilidad de una iniciativa popular en el terreno legislativo, y es sabido que una iniciativa popular en el terreno legislativo puede dar lugar a leyes, y todos sabemos que una ley posterior deroga a otra y es una forma también de derogar una ley existente". Un argumento este - también esgrimido por M. Roca en este mismo debate - que semeja un tanto falaz, pues equipara dos instituciones que se desenvuelven en planos distintos: la iniciativa legislativa popular, cuyos efectos solo son propositivos, con una iniciativa susceptible de desembocar en un referendo vinculante.

Otros intervinientes abundaron en esta línea. Así, J. P. Pérez-Llorca, de UCD, estimó que el referendo legislativo previsto en el anteproyecto "podía llevar a una técnica de veto plebiscitario", y que el derogatorio planteaba "problemas similares, cuando no más delicados aún, (...) sobre todo si se pone en contacto con la iniciativa popular". El diputado socialista G. Peces-Barba, por su parte, expresó con toda claridad una posición de extrema desconfianza ante la institución del referendo, que "puede suponer la manipulación de la pregunta; puede dividir, en algunos aspectos, al país en dos grandes bloques, lo cual no es positivo en este momento; puede simplificar los temas, y puede, incluso en algunos aspectos, como se está viendo en la práctica italiana, ser (...) justamente una práctica antidemocrática". Conviene recordar aquí que J. Solé Tura, M. Roca, J. P. Pérez-Llorca y G. Peces-Barba habian formado parte de la ponencia constitucional y habian sido, por tanto, redactores del artículo 85 del anteproyecto en el que ahora tantos peligros veían confluir. Frente a todos ellos, M. Fraga Iribarne fue quien principalmente defendió la propuesta de la ponencia, aduciendo en favor del referendo abrogativo que "la soberanía no está en el Parlamento en nuestra Constitución (...) y justamente esta ventana abierta a las fuerzas sociales, a través del referéndum de iniciativa popular, (...) es sumamente conveniente para una verdadera democracia", y criticando el carácter consultivo del referendo porque, una vez emitido mayoritariamente el parecer del pueblo, "no tomar en consideración la opinión expresada (...) es de la más extrema gravedad". Por todo ello, la aceptación de la enmienda le parecía "una decisión enormemente regresiva y antidemocrática".

A nuestro entender, la sesión de la Comisión de Asuntos Constitucionales y Libertades Públicas del día 6 de junio marcó un punto de inflexión. Después de su celebración, las posiciones de las principales fuerzas políticas quedaron fijadas en lo esencial, en cuanto a la institución del referendo en concreto y a la participación politica directa en general. Mientras que los partidos de la izquierda y la UCD se afirmaron en una acentuada desconfianza, Alianza Popular asumiría en lo sucesivo el papel de gran valedor de estas instituciones participativas a las que M. Fraga solía referirse como "democracia semidirecta".

Pocos días después de vaciar casi por completo de contenido el art. 86 del Proyecto de Constitución, el 20 de junio, la comisión iba a derribar otros dos puntales del régimen de participación política directa ideado por la ponencia constitucional: la iniciativa popular para la reforma de la Constitución y el referendo obligatorio para toda reforma constitucional; para ello, se volvieron a utilizar como ariete sendas enmiendas in voce, en este caso planteadas por el diputado G. Cisneros, de UCD, y secundadas por nacionalistas, socialistas y comunistas. 
La primera de estas enmiendas modificaba la redacción del artículo 157 del anteproyecto $^{43}$. En su virtud, se sustituyó la remisión genérica al artículo regulador de la iniciativa legislativa por una remisión parcial a sus tres primeros puntos, de modo que el Gobierno, el Congreso, el Senado y las asambleas autonómicas pasaban a ser los únicos órganos constitucionales legitimados para proponer la reforma o la revisión de la Constitución. Solo el representante de Alianza Popular, M. Fraga, se pronunció y votó en contra de este cambio ${ }^{44}$.

La segunda de ellas suponía un cambio relevante en la regulación de la reforma constitucional. Formalmente, la desglosaba en dos artículos - 161 y 162 del dictamen - y, desde un punto de vista material, introducía una delimitación nueva de los supuestos objeto del procedimiento agravado de reforma - una revisión total o una parcial que afectase al Título Preliminar, al Capítulo II, Sección $1^{\text {a }}$ del Título I o al Título II -, a los que se limitaba ahora el referendo obligatorio para la ratificación popular. En los restantes casos, sujetos al procedemiento ordinario, el referendo solo procedería a solicitud de la décima parte de los diputados o de los senadores. En definitiva, el referendo sobre la reforma de la Constitución, concebido como obligatorio en su primera versión, quedaba reducido en la práctica a poco más que un referendo facultativo de iniciativa parlamentaria, dada la extrema rigidez del procedimiento agravado y la enorme dificultad de su realización ${ }^{45}$.

43 Artículo 160 del dictamen de la Comisión de Asuntos Constitucionales y Libertades Públicas del Congreso: "La iniciativa de reforma constitucional se ejercerá en los términos previstos en los párrafos primero, segundo y tercero del artículo 81". Esta redacción excluye de la iniciativa de reforma constitucional a la iniciativa popular, contemplada en el párrafo cuarto del artículo 81 del dictamen.

44 Diario de Sesiones del Congreso de los Diputados, núm. 93, de 20 de junio de 1978, pp. 3462-3466, donde se reproducen las intervenciones en el debate sobre la enmienda formulada in voce de G. Cisneros. Este diputado justificaba la supresión de la institución porque "la apertura de la iniciativa de la reforma constitucional a la iniciativa popular desnaturalizaría ciertamente la configuración que de la reforma constitucional hace el artículo 160”. Más lejos aún llegó en su descalificación G. Peces-Barba, entendiendo que se trataba de una institución que podía "causar graves daños a la democracia" y que le recordaba "mucho más a los referéndums de los sistemas autoritarios que a la democracia semidirecta en un régimen democrático". Una afirmación que, referida a lo que no pasaba de ser un mero mecanismo de iniciativa, propositivo y nunca decisivo, parece como poco exagerada. M. Fraga, por su parte, calificó de "error grave" el nuevo "recorte a la democracia semidirecta", y consideró "frustrador este proceso que estamos siguiendo desde hace unas semanas de restringir todo lo que podemos las iniciativas populares directas".

45 Los debates sobre la redacción de estos preceptos puede consultarse en el Diario de Sesiones del Congreso de los Diputados, núm. 93, de 20 de junio de 1978, pp. 3466 y ss. Frente a las acusaciones de M. Fraga, que veía en la supresión del referendo obligatorio en todos los casos de reforma constitucional "otro nuevo tajo que se le quiere dar a la democracia semidirecta" (p. 3468) y "un nuevo paso atrás en el camino hacia la democracia, y un nuevo paso peligroso en la dirección de la partitocracia" (p. 3469). G. Cisneros la consideraba "una cautela prudente" y sobre la movilización de una décima parte de los miembros de una Cámara para pedir el referendo opinaba que "no es fácil excluir que esa será una posibilidad realista, la del ejercicio de ese derecho por una minoría tan poco cualificada de parlamentarios que permitirá, en todo caso, no sustraer al conocimiento general popular una decisión de reforma constitucional que merezca la pena" (p. 3474). Una opinión que se ha visto rotundamente desmentida por lo acontecido con ocasión de la reforma del art. $135 \mathrm{CE}$; en opinión de A. Rodríguez Bereijo "una modificación —la primera de alcance verdaderamente sustancial desde 1978- llevada a cabo por el acuerdo de las dos grandes fuerzas politicas nacionales (PSOE y PP) sin el consenso de los demás partidos, minoritarios" y, por tanto, con "ruptura, pues, del consenso constituyente originario de 1978 y, lo que es más importante, sin la apelación al pueblo soberano, como cuerpo electoral, para su 
Finalizados los trabajos de la comisión, la fisonomía de la participación política directa en su dictamen no permitía reconocer apenas el inicial dibujo que de la misma habian plasmado los siete ponentes en el anteproyecto: desaparecidos el referendo previo a la promulgación de leyes y el referendo abrogativo, eliminado todo vestigio de iniciativa popular para promover consultas referendarias, suprimida la iniciativa popular para la propuesta de reformas constitucionales y capitidisminuido el referendo sobre la reforma constitucional, solo permanecían en el texto del dictamen el referendo sobre decisiones politicas de especial trascendencia, aunque con carácter meramente consultivo y solo a propuesta del Gobierno, y la iniciativa legislativa popular, si bien la configuración de esta quedaba en gran medida al albur de lo que pudiese decidir en su momento el legislador orgánico. Un esquema que reflejaba un nuevo consenso en la materia, transformado, que sometía a la participación política directa a una intensa restricción constitucional y que ya no iba a sufrir variaciones en los debates subsiguientes. Todos los preceptos comentados fueron finalmente incorporados al Proyecto de Constitución aprobado por el Congreso en los exactos términos del dictamen de la comisión.

\subsection{El trámite en el Senado}

Vistas la correlación de fuerzas en el Senado y la solidez del consenso alcanzado en el Congreso en torno a la limitación constitucional de los instrumentos de participación politica directa, no eran de esperar grandes cambios durante el trámite del Proyecto de Constitución en esta cámara. El debate en la Comisión Constitucional del Senado hizo posible, no obstante, que se escucharan nuevas propuestas y argumentos para aumentar la presencia de estas instituciones en la Constitución y facilitar su ejercicio, en ocasiones defendidos de forma brillante pero desatendidos en todo caso. Así, a las enmiendas e intervenciones del senador de Alianza Popular F. Cacharro ${ }^{46}-$ integrado en el Grupo Mixto -, que reproducian en buena medida las de M. Fraga en el Congreso, se sumaron las voces de otros senadores. Cabe destacar, de entre ellas, la del independiente L1. M. Xirinacs, quien propuso a través de 133 enmiendas un auténtico proyecto alternativo de Constitución basado en el modelo confederal que incluía propuestas avanzadas en relación con el tema que nos ocupa, como una iniciativa legislativa popular con un requisito de cien mil suscriptores, la iniciativa ciudadana para impulsar el referendo sobre decisiones politicas de especial trascendencia - con el aval de doscientas mil firmas - o la iniciativa popular para la reforma de la Constitución ${ }^{47}$. También merecen ser

ratificación a través del referéndum". Álvaro Rodríguez Bereijo, "La reforma constitucional del artículo 135 CE y la crisis financiera del Estado", Crónica presupuestaria, Vol. 1., 2013, p. 6.

46 Las Enmiendas del Senado al Proyecto de Constitución pueden consultarse en http://www.congreso.es/constitucion/ficheros/enmiendas/enmsenado.pdf [consultado: 1-122016]. F. Cacharro, en la enmienda núm. 194, proponía la recuperación tanto del referendo legislativo como del derogatorio, admitiendo para este la iniciativa popular, en la línea de la propuesta inicial de la Ponencia constitucional, así como la iniciativa popular para la reforma de Constitución y el referendo en todos los casos de modificación constitucional. Enmiendas del Senado al Proyecto de Constitución, op. cit., pp. 79, 81 y 82.

47 Enmiendas núm. 510, 515 y 563. Enmiendas del Senado al Proyecto de Constitución, op. cit., pp. 215, 217 y 239. L1. M. Xirinacs aportó, además, razones y reflexiones de gran interés y se mostró muy crítico con los partidos de izquierda, a los que culpaba del declinar de estas 
mencionadas las enmiendas e intervenciones de R. Audet ${ }^{48}$ - de Esquerra Republicana -, quien realizó una aguda crítica del carácter consultivo del referendo, configuración que consideraba inconsecuente con la proclamación constitucional de la soberanía popular, de M. Villar Arregui ${ }^{49}$ - del grupo de los Progresistas y Socialistas Independientes -, en relación con la iniciativa legislativa popular, y de la senadora por designación real M. B. Landáburu ${ }^{50}$, sobre los referendos constitucionales. Los esfuerzos de todos ellos resultaron a la postre infructuosos, y el Senado no aprobó ningún cambio significativo en materia de participación política directa ${ }^{51}$.

instituciones a lo largo del iter constituyente. Así, por ejemplo, en la justificación de la segunda enmienda citada señalaba, agudamente, que la iniciativa popular del referendo era necesaria "por respeto al derecho a la participación directa de los ciudadanos en los asuntos públicos enunciado en el artículo 23". Por otra parte, la exigencia de quinientas mil firmas para la iniciativa legislativa popular le parecía "una cosa dificilísima", que entraba "dentro del capítulo de las dificultades que suelen poner los políticos a la democracia directa"; y, en cuanto al argumento de la posible manipulación por grupos extremistas o minoritarios de los referendos, Xirinacs lo refutaba lúcidamente como sigue: "A mí me da la impresión, al revés, de que el referéndum es más bien mayoritario que minoritario, y que todos estos partidos que se glorian de tener detrás de sí grandes cantidades de masas tendrian que estar muy contentos de que se ampliara la Ley de Referéndum, porque les daría la razón a ellos. (...) Da un poco la impresión de que los partidos tienen miedo al pueblo y lo quieren como amordazar". Diario de Sesiones del Senado, núm. 49, de 5 de septiembre de 1978, pp. 2282 y 2303, respectivamente.

48 Enmienda núm. 415, en la que se propone la supresión del carácter consultivo del referendo. Enmiendas del Senado al Proyecto de Constitución, op. cit., 178. R. Audet, en sede plenaria, defendía así la enmienda, reconvertida en voto particular: "Es del todo absurdo que, residiendo la soberanía en el pueblo, un referéndum sea tan solo consultivo. No es lógico ni consecuente que una vez que el pueblo se haya definido sobre un proyecto o una decisión política importante se haga caso omiso de su parecer o criterio, o se le haga un caso muy relativo. Un referéndum solo tiene por objetivo conocer la voluntad popular, y si, tal como se afirma en el artículo 1 de esta Constitución, la soberanía reside en el pueblo, su voluntad, libremente expresada, debe ser respetada por los poderes públicos que lo representan. (...). Hace falta, por tanto, abandonar de una vez por todas los sentimientos y sentimentalismos paternalistas con relación al pueblo, aceptando con todas sus consecuencias la voluntad expresada en su voto". Diario de Sesiones del Senado, núm. 63, de 30 de septiembre de 1978, p. 3147.

49 Enmiendas núm. 56, en la que se plantea una iniciativa legislativa popular con un requisito de cien mil firmas y con menos limitaciones, y núm. 95, en la que se propugna la recuperación de la iniciativa popular para proponer la reforma de la Constitución. Enmiendas del Senado al Proyecto de Constitución, op. cit., pp. 30 y 44.

50 Enmienda núm. 439, que propugnaba recuperar la obligatoriedad del referendo para la aprobación de toda reforma constitucional. Enmiendas del Senado al Proyecto de Constitución, op. cit., p. 187.

51 De hecho, salvedad hecha del cambio en la numeración de los artículos, en el trámite del Senado solo se introdujeron dos modificaciones de carácter formal al texto del proyecto remitido por el Congreso. El artículo 165 (antes 160) cambió por concordancia con el artículo 86 (antes 81), en el que se había suprimido un párrafo con el correlativo cambio de numeración, y quedó redactado como sigue: "La iniciativa de reforma constitucional se ejercerá en los términos previstos en los párrafos primero y segundo del artículo 86". Por otra parte, el artículo 91.2 (antes 86.2) pasó a decir que "el Rey convocará el referéndum con refrendo del Presidente del Gobierno y previa autorización del Congreso de los Diputados"; más adelante la Comisión Mixta CongresoSenado modificó a su vez esta redacción, dándole la que sería definitiva (art. 92.2 CE): "El referéndum será convocado por el Rey, mediante propuesta del Presidente del Gobierno, previamente autorizada por el Congreso de los Diputados". 


\subsection{La actuación de la Comisión Mixta Congreso-Senado: último golpe a la participación politica directa}

Sin embargo, aún estaba por llegar el último golpe a la participación política directa, asestado por la Comisión Mixta Congreso-Senado. De acuerdo a lo previsto en la Ley para la reforma politica, este órgano estaba llamado a solventar las discrepancias entre ambas cámaras, fijando un texto definitivo de la Constitución que fuese sometido a los respectivos plenos. No obstante, además de resolver dichas diferencias, la Comisión Mixta también modificó algunos preceptos constitucionales sobre los que no había divergencias o, si las habia, eran solamente de matiz o de estilo, asumiendo un papel creador que no le correspondía y que constituye, en nuestra opinión, uno de los aspectos más criticables del proceso constituyente español. Esto fue, precisamente, lo ocurrido con la iniciativa legislativa popular: a pesar de no existir la más mínima diferencia entre la redacción del artículo 81.4 del proyecto aprobado por el Congreso y la del artículo 86.3 del texto del Senado, la Comisión Mixta rectificó de modo sustantivo el contenido de la norma, y lo hizo en un sentido intensamente restrictivo, añadiendo a las exclusiones materiales que ya contemplaba el precepto la de las "materias propias de ley orgánica". Con ello, situaba fuera del alcance de la iniciativa popular la proposición de leyes en un amplísimo abanico de temas, tan sensibles como el sistema electoral o los derechos fundamentales y las libertades públicas, entre otros. Las dificultades para explicar las razones de este último recorte de la participación política directa se acrecientan por el secreto de las deliberaciones de la Comisión Mixta, aunque parece claro, teniendo en cuenta la adscripción politica de sus miembros ${ }^{52}$ y el evidente receloque, sobre todo, el grupo de UCD había demostrado ante la iniciativa legislativa popular, que se aprovechó la ocasión y sus circunstancias para reducir la potencialidad de esta institución al mínimo posible.

\section{EL INSUFICIENTE RECONOCIMIENTO CONSTITUCIONAL DE LA PARTICIPACIÓN POLÍTICA DIRECTA}

Aunque la Constitución contiene algunos preceptos reconocedores de formas de participación política directa, dicho reconocimiento se realiza de forma muy poco generosa en cuanto a su extensión e intensidad, pudiéndose afirmar que la recepción constitucional de este género de instituciones, como resultado de los avatares que hemos pormenorizado en los puntos precedentes, fue cautelosa e incluso cicatera ${ }^{53}$. En contraste, como hemos visto, el anteproyecto constitucional

52 La comisión estaba presidida por el Presidente de las Cortes, A. Hernández-Gil, y de ella formaron parte los presidentes respectivos del Congreso y del Senado, F. Álvarez de Miranda y A. Fontán (ambos de UCD), J. P. Pérez-Llorca (de UCD), A. Guerra (del PSOE), el comunista J. Solé Tura, el nacionalista catalán M. Roca, dos senadores de UCD (A. Jiménez Blanco y F. Abril Martorell) y dos senadores socialistas (J. Vida Soria y F. Ramos).

53 Antonio Torres del Moral, "El Estado español como Estado social y democrático de Derecho y como democracia representativa y pluralista", en V. Gimeno Sendra, A. Torres del Moral, P. Morenilla Allard y M. Díaz Martínez, Los derechos fundamentales y su protección jurisdiccional, Colex, Madrid, 2007, p. 44. Valoraciones parecidas podemos encontrar en otros autores que han escrito sobre el tema. Valgan, a título de ejemplo, las que siguen: Elviro Aranda Álvarez, "La nueva Ley de la Iniciativa Legislativa Popular", Revista española de Derecho Constitucional, núm. 78, 2006 , p. 193, que entiende que la regulación constitucional se realiza "con un importante número de reservas y limitaciones”. Ángel Garrorena Morales, El Estado español como Estado social y democrático de Derecho, Tecnos, Madrid, 1992, pp. 146-147, para quien dicha regulación "es, sin 
contenía una amplia recepción de las instituciones de participación política directa que fue notablemente mermada en el debate constituyente posterior. Así, aunque se mantuvo finalmente en el texto constitucional la iniciativa legislativa popular, se la rodeó de cautelas y limitaciones extraordinarias, manifestadas en la exigencia de un número muy elevado de suscriptores $\mathrm{y}$, sobre todo, en una rigurosa limitación material, que dejó fuera de su ámbito a la legislación tributaria, a las materias internacionales, a la prerrogativa de gracia y, merced al inesperado cambio de última hora operado por la Comisión Mixta CongresoSenado, a todas las materias propias de ley orgánica. La iniciativa popular para la reforma constitucional, prevista en el anteproyecto, fue eliminada en el debate constituyente. Y, en cuanto a la ordenación constitucional del referendo, la avanzada propuesta del anteproyecto - consultas vinculantes, con diversidad de objetos y con posibilidad en ciertos casos de iniciativa popular para su impulso fue laminada y solo quedó constitucionalizado, al margen de los referendos autonómicos y de reforma constitucional, el referendo consultivo del art. $92 \mathrm{CE}$. La opción final del constituyente español de 1978 fue, por tanto, la de disciplinar de modo restrictivo la participación democrática directa de los ciudadanos, participación que, de modo simultáneo, era reconocida en el art. $23 \mathrm{CE}$ como derecho fundamental, en aparente pie de igualdad con la participación por medio de representantes.

¿Qué razones llevaron al constituyente a regular de un modo tan austero los instrumentos de participación directa? Algunas de las circunstancias coetáneas al proceso, así como ciertos argumentos esgrimidos por los intervinientes, han sido objeto de comentario en el punto precedente. Pero es preciso, a nuestro juicio, avanzar un tanto más allá e intentar construir una explicación integral del proceso evolutivo que medió entre la propuesta inicial de los ponentes y el resultado constitucional final, tratando de determinar cuáles fueron las auténticas motivaciones de sus actores y si estas eran razonables, si hubo verdaderamente un viraje a la altura del ecuador del proceso constituyente, influido por circunstancias muy concretas, y, por último, si los factores concurrentes hacian aconsejable adoptar las decisiones que se tomaron o si, por el contrario, los constituyentes se dejaron llevar más allá de lo exigido por ellos. En fin, si se puede calificar, ponderado lo anterior, de insuficiente la acogida de la participación política directa en el texto constitucional definitivo.

\subsection{Las razones de los constituyentes}

Cuando se ha escrito sobre el tema, la generalizada limitación constitucional que sufrieron las instituciones de participación politica directa durante el iter constituyente se ha relacionado, normalmente, con el momento histórico de la transición democrática en España, con algunas experiencias no demasiado positivas procedentes del Derecho comparado y con los temores y preocupaciones de los parlamentarios sobre un posible uso desviado de los mismos, bien por parte del gobierno de turno, bien por grupos extremistas que pudiesen encontrar en ellos el instrumento idóneo para desestabilizar una democracia escasamente

duda, restrictivamente cauta". Miguel Ángel Presno Linera, "La participación ciudadana en el procedimiento legislativo como parte de la esencia y valor de la democracia”, op. cit., p. 96: "Las previsiones constitucionales a propósito de la iniciativa legislativa popular han sido especialmente mezquinas". 
asentada ${ }^{54}$. En nuestra opinión, las razones derivadas de la coyuntura histórica fueron sin duda las determinantes. Tras varias décadas de régimen autoritario y en un momento de transición política donde muchos resortes del poder seguian controlados por los mismos sujetos que en la etapa anterior, consolidar una democracia parlamentaria de corte europeo y un sistema pluralista de partidos políticos era una necesidad sentida a la que se supeditaron cualesquiera otras consideraciones ${ }^{55}$. A ello se sumaba la relativa proximidad temporal del último referendo franquista, convocado en 1966 - para la aprobación de la Ley Orgánica del Estado -, que podia inspirar una cierta asociación entre la apelación plebiscitaria al pueblo y el recuerdo odioso de la dictadura.

No obstante, es muy probable que otras motivaciones contribuyesen igualmente a predisponer a los principales grupos políticos en contra de mantener una presencia significativa de las instituciones de democracia participativa en la Constitución que estaban debatiendo. Así, pudo jugar un papel relevante una específica concepción del parlamentarismo extendida entre amplios sectores de los constituyentes, celosa a la hora de preservar la primacía institucional del parlamento $\mathrm{y}$, a su través, la de una clase política muy refractaria a cualquier recorte en su recién estrenada posición ${ }^{56}$; o, dicho de otro modo, es presumible que en el imaginario de muchos diputados y senadores cobrase progresivamente fuerza, como elemento simbólico, la idea de una "soberanía de las cámaras" como única expresión válida de la soberanía del pueblo, en parte como reacción - tal vez exacerbada, pero seguramente lógica - a la prolongada negación de cualquier atisbo de democracia representativa en España, pero también porque los partidos politicos recientemente reconocidos veían en esta idea una garantía de su estatus y en la "democracia directa" un

\footnotetext{
54 Cfr., por ejemplo, Alfredo Ramírez Nardiz, "El debate en torno a los mecanismos de democracia participativa durante el proceso constituyente español", op. cit., pp. 168-170. Para Elviro Aranda Álvarez, "La nueva Ley de la Iniciativa Legislativa Popular", op. cit., pp. 192-193, las experiencias negativas procedentes del Derecho comparado fueron determinantes, pero también "el esfuerzo, y seguro bien intencionado empeño, por consolidar la democracia representativa y el Estado de partidos". O. Alzaga, que tuvo participación directa en el debate, también ha destacado, desde su autorizada visión, la relevancia de los factores vinculados a la coyuntura histórica: "Nuestros constituyentes, que, de un lado, no habian olvidado los referenda franquistas, sistemáticamente enmarcados en la propaganda oficial y unidireccional en favor del sí de turno y que, de otro, deseaban consolidar el sistema de partidos politicos como principales herramientas de la democracia representativa y que, además, albergaban algún temor a las posibilidades que podían tener los grupos extremistas de derecha e izquierda a la hora de manejar mecanismos extraparlamentarios, fueron muy cautos en la instauración de dispositivos de participación popular directa" (Óscar Alzaga, Ignacio Gutiérrez et al., Derecho politico español según la Constitución de 1978. II. Derechos fundamentales y órganos del Estado, Editorial Universitaria Ramón Areces, Madrid, 2011, p. 146); aunque también ha reconocido el papel de los ejemplos foráneos, admitiendo que pesó en forma determinante "el hecho de que la inmensa mayoría de las fuerzas politicas concurrentes en nuestro proceso constituyente estimasen como negativa la experiencia italiana, donde el referendo abrogativo ha generado no pocos problemas y enturbiado un tanto el ambiente político, lo que ha facilitado un campo de juego idóneo a los partidos politicos marginales y extraparlamentarios y, a la par, ha permitido sacar de los muros de los edificios que albergan las Cámaras las contiendas politicas para llevarlas a la calle" (Óscar Alzaga Villaamil, Comentario sistemático a la Constitución española de 1978, op. cit., p. 581).
}

55 Antonio Torres del Moral, "El Estado español como Estado social y democrático de Derecho y como democracia representativa y pluralista", op. cit., pp. 44-45.

56 Ángel Garrorena Morales, El Estado español como Estado social y democrático de Derecho, op. cit., pp. 146-147. 
riesgo de perderlo. Todos estos factores vinieron a confluir, en mayor o menor medida, en una disposición de máxima precaución y cautela frente a la amplia apertura constitucional a la participación politica directa del pueblo que programaba el anteproyecto de la Constitución.

En cuanto a la perspectiva del Derecho comparado, aunque afloró repetidamente en los debates, nos parece que intervino más como argumento que como motivación de fondo, puesto que, rigurosamente hablando, experiencias las había de todos los tipos y con frutos de lo más dispares, algo que no podian ignorar los constituyentes. Sin embargo, la concreta cuestión de los referendos abrogativos promovidos en Italia por el Partido Radical y llevados a efecto el día 11 de junio de 1978, la elevada participación en los mismos y su resultado, fue, con toda probabilidad, el ingrediente decisivo que puede explicar el giro sufrido en materia de participación politica directa a partir de la sesión de la Comisión de Asuntos Constitucionales y Libertades Públicas del Congreso celebrada el 6 de junio. Cuando en el ambiente del debate ya eran palpables las reticencias de muchos ante la constitucionalización de figuras referendarias o de iniciativa popular, los sucesos de Italia y los riesgos que evidenciaron, sobre todo para el rol central y preponderante de los partidos en el sistema político, actuaron como agente desencadenante de un acuerdo tácito tendente a limitar la incidencia de estos instrumentos en la nueva democracia española.

Es muy significativo el hecho de que los constituyentes conservadores se mostrasen proclives en el debate constitucional a reforzar los mecanismos de participación política directa, mientras que los más comprometidos con la democracia fueron los principales artífices de su devaluación final. Sin duda influyó en ello la preocupación, palpable entre muchos constituyentes, de que en los primeros tiempos de una democracia todavía sin afianzar los referendos o las iniciativas populares pudiesen utilizarse para desestabilizar la propia democracia, o para comprometer o forzar, desde posiciones reaccionarias, el retroceso de los logros políticos o sociales que se pudiesen ir alcanzando. Una prevención que ya fue manifiesta en el año 1931 en las constituyentes republicanas y que con la recuperación de las libertades reaparecia, pero que no explica por sí sola por qué los parlamentarios de la izquierda española, que mostraron una postura indefinida en las primeras fases del proceso constituyente, acabaron por suscribir los puntos de vista más negadores de la participación politica directa, alejándose de concepciones de la democracia que teóricamente les podian resultar más propios.

Quizá los temores más determinantes - a la par que los menos explícitos fueron los relacionados con el posible menoscabo de los partidos politicos y de su función constitucional en el Estado, que las organizaciones de izquierda identificaban en gran medida con la democracia - también aquí es visible un componente de impulso reactivo frente a la negación absoluta del pluralismo político durante el régimen anterior - y que se mostraron dispuestas a proteger a toda costa, renunciando incluso a elementos ideológicos que en teoría defendian. Por su parte, la postura de los constituyentes más vinculados al anterior régimen se puede explicar - más fácilmente - desde idéntico punto de vista, ya que su recelo ante el sistema de partidos, comprensible habida cuenta de sus origenes políticos, se tradujo en un reiterada advertencia, a lo largo de todo el proceso, 
frente a los riesgos de la "partitocracia" 57 y, en consonancia con ella, en la reivindicación de instrumentos jurídicos capaces de articular la participación política al margen de los partidos.

\subsection{Los argumentos de los constituyentes}

Los argumentos vertidos por los constituyentes de inclinación más democrática para propugnar la férrea limitación de la participación política directa que finalmente resultó fueron de diverso tenor y no guardaron siempre una correlación exacta con las motivaciones expuestas. Las alusiones concretas a los referendos italianos de junio fueron escasas y la aspiración a construir un modelo de democracia donde el predominio de los partidos políticos quedase garantizado no fue casi nunca explicitada, mientras que se prodigaron los argumentos basados en la defensa de la "pureza" parlamentaria. Fue el diputado comunista y ponente constitucional J. Solé Tura quien más claramente manifestó, en réplica a las constantes acusaciones por parte de M. Fraga de promover la partitocracia, la preocupación por el estatus de los partidos politicos: "El problema que tenemos en nuestro país, y no solo en nuestro país, es consolidar un sistema de partidos que hoy es tremendamente precario y esta consolidación exige que los mecanismos constitucionales, entre otras cosas, la favorezcan. (...) La democracia semidirecta no se ejerce solo ni principalmente por la vía plebiscitaria, sino que significa prever en la Constitución formas de participación, y esas formas de participación (...) pueden revestir la forma de partidos políticos a los cuales se les reconoce constitucionalmente todo el rango que deben tener"58. En otros momentos, sin embargo, este diputado apeló a la soberanía del parlamento para justificar sus reticencias en relación con el referendo legislativo que le parecía abrir "una extraña posibilidad de que la soberanía del Parlamento sea absolutamente menoscabada", mientras que una consulta vinculante sobre decisiones politica de especial trascendencia "puede dar lugar también a que el Parlamento quede absolutamente colocado en un segundo plano", puesto que "si decimos que las Cortes representan al pueblo, y el pueblo español representa la soberanía, estamos diciendo algo en concreto y lo que no queremos es que se introduzcan en ese proceso normal de la representación y decisión, elementos que puedan coartarlo o que puedan tergiversarlo o minimizarlo"59. Argumentos parecidos se usaron en otros

57 M. Fraga se refirió en numerosas ocasiones a los peligros que para la democracia comportaba la "partitocracia", que "podia ser una de las más graves consecuencias" de las decisiones tomadas para restringir la participación politica directa (Diario de Sesiones del Congreso de los Diputados, núm. 81, de 6 de junio de 1978, p. 2941). La partitocracia llegaría a existir en el momento "en el cual los partidos no actúan como promotores de corrientes de opinión, de programas y de candidatos, sino como monopolizadores del proceso político" lo que haría necesarias "vias complementarias, justamente para evitar que los partidos, como he dicho antes, suplanten la voluntad popular". (Diario de Sesiones del Congreso de los Diputados, núm. 109, de 15 de junio de 1978, p. 4219). Para ilustrar el peligro de transformación de la democracia en partitocracia, M. Fraga trajo a colación la obra del teórico de la participación P. L. Zampetti e incluso de pensadores referente de la izquierda, como A. Gramsci (Diario de Sesiones del Congreso de los Diputados, núm. 81, de 6 de junio de 1978, p. 3469).

58 Diario de Sesiones del Congreso de los Diputados, núm. 93, de 20 de junio de 1978, p. 3466.

59 Diario de Sesiones del Congreso de los Diputados, núm. 81, de 6 de junio de 1978, pp. 2937 y 2942. 
momentos, como hizo, por ejemplo, el también ponente constitucional J. P. PérezLlorca ante el pleno del Congreso: "En el fondo estamos aquí ante un problema valorativo de si vale más la pena que asentemos con nitidez el sistema parlamentario en toda su pureza, en nuestra Constitución, o lo podamos hacer convivir con otros sistemas cuya eficacia en un sistema parlamentario no está probada. (...) Si con carácter constitucional adjuntáramos al sistema parlamentario unos instrumentos de democracia directa o semidirecta, estaríamos haciendo un régimen híbrido, que es un concepto que no tiene nada que ver con el régimen mixto, $y$ estariamos haciendo un régimen extraordinariamente frágil"60.

También exhibieron los constituyentes, en alguna ocasión, el recuerdo de los referendos franquistas para negar la virtud democrática de las consultas populares. A ello recurrió, por ejemplo, G. Peces-Barba, a quien la iniciativa popular para la reforma constitucional le recordaba - aunque es obvio que no se refería solo a esta institución - "a las fórmulas plebiscitarias o incluso a esas agrupaciones de ciudadanos que se producian para aclamar a los líderes de los regímenes autoritarios en la época del General Perón o del General Franco"61.

A cambio, se desvirtuaron las experiencias prácticas del Derecho comparado y se exageraron los riesgos para la democracia asociados a un reconocimiento extenso de la participación politica directa ${ }^{62}$. De hecho, el peligro que para el sistema democrático podía suponer el uso interesado de los mecanismos de democracia directa por grupos extremistas fue uno de los argumentos más recurridos. Aunque se registraron varias intervenciones en esta línea de argumentación, baste citar la de J. P. Pérez-Llorca en sede plenaria, quizá la más remarcable: “(...) si constitucionalizamos los supuestos que plantea el señor Fraga, si los reglamentamos dentro de la Constitución en este momento de implantación del nuevo sistema, todos ellos podrían producir conflictos graves; conflictos graves entre las Cámaras y el pueblo, conflictos graves entre las Cámaras y el Gobierno. (...) Es evidente, al menos a mí me lo parece, que el supuesto de referéndum, que interviene entre el momento de aprobación de una ley por ambas Cámaras y la sanción regia, es un supuesto enormemente conflictivo cuya introducción en la Constitución, unida a la iniciativa popular, podría dejar en manos de minorias fuertemente organizadas la suerte de leyes debatidas en las Cámaras, e incluso la suerte de esas propias Cámaras. Es igualmente cierto, a mi juicio, que el referéndum abrogativo, unido a la iniciativa popular, podría plantear, en este momento inaugural de inicio del sistema constitucional en España, conflictos gravísimos. Y esta es una cuestión política que no podemos eludir, ya que podrian ser planteados por minorias, por grupos extraparlamentarios minoritarios, y en ciertas cuestiones concretas podrían crear conflictos graves al funcionamiento adecuado del sistema"63.

60 Diario de Sesiones del Congreso de los Diputados, núm. 109, de 15 de junio de 1978, p. 4213.

${ }^{61}$ Diario de Sesiones del Congreso de los Diputados, núm. 93, de 20 de junio de 1978, p. 3465.

62 Miguel Ángel Presno Linera, "La participación ciudadana en el procedimiento legislativo como parte de la esencia y valor de la democracia", p. 90.

63 Diario de Sesiones del Congreso de los Diputados, núm. 109, de 15 de junio de 1978, pp. 4213. 
La consistencia de estos argumentos es bastante dudosa. Durante el franquismo solo se utilizó el referendo en dos ocasiones, en 1947 y en 1966, pero, en cualquier caso, estos referendos no pueden considerarse como una manifestación democrática de ningún tipo. Y también hay procesos "electorales" en las dictaduras - incluida la de Franco - sin que por ello se pueda deducir el carácter reaccionario de todo proceso electoral ${ }^{64}$. El anhelo de reencuentro con los esquemas típicos de un régimen parlamentario "puro", por otra parte, pone de manifiesto una visión de la democracia un tanto miope por parte de los constituyentes más "progresistas", incapaces de detectar que los patrones clásicos ya estaban superados por la realidad de un parlamentarismo en extremo racionalizado y de unas democracias cada vez más plebiscitarias; y de entender que la participación política directa de los ciudadanos no es inconciliable con el pluralismo político ni supone un obstáculo para el funcionamiento de la democracia representativa. Muy al contrario, puede enriquecer a esta y contribuir a integrarla en un paradigma de democracia participativa, dotándola de mayor legitimidad democrática y devolviéndole su capacidad para vehicular la evolución social.

\subsection{Las tesis del riesgo}

Por último, nos referiremos al empleo de la que A. Hirschman denomina, dentro de las retóricas de la intransigencia, la "tesis del riesgo", un elemento discursivo recurrente frente a todos los desarrollos teóricos y propuestas prácticas que han intentado formular proyectos alternativos al orden establecido, tanto en el plano político como en el social o el económico, a lo largo de la historia $^{65}$. Razones similares, por ejemplo, fueron esgrimidas contra la ampliación del sufragio, primero a los hombres no propietarios y luego a las mujeres, han vuelto a reiterarse cada vez que se ha planteado una posible rebaja de la edad electoral, y han estado igualmente presentes como parte del ideario reaccionario frente a todo intento de extensión de los derechos civiles a minorias discriminadas en cuanto a su disfrute.

El recurso a la tesis del riesgo para intentar desarmar la reivindicación de más participación directa de los ciudadanos en las decisiones públicas aparece, como hemos visto, desde el primer momento, pero se perpetúa en el tiempo. Así, se ha seguido utilizando cada vez que dicha reivindicación ha saltado a la palestra, a pesar de que las circunstancias del contexto social y político actual, tras décadas de régimen constitucional y con una democracia consolidada, nada tienen que ver con las de la transición política española. Lo que pone de relieve, en definitiva, su carácter de argumentos engañosos, que esconden las

64 Antonio Torres del Moral, "El Estado español como Estado social y democrático de Derecho y como democracia representativa y pluralista", op. cit., p. 45.

65 Cfr. Albert O. Hirschman, Retóricas de la intransigencia, Fondo de Cultura Económica, México, 1991, pp. 97 y ss. Cuando se hace uso de la "tesis del riesgo" se afirma que el costo politico y social de las reformas propuestas es considerablemente alto y pone en peligro logros precedentes. M. A. Presno Linera ha puesto de manifiesto cómo este tipo de argumentos fueron ampliamente usados en el debate constituyente respecto a la constitucionalización de mecanismos de participación política directa. Cfr. Miguel Ángel Presno Linera, "La participación ciudadana en el procedimiento legislativo como parte de la esencia y valor de la democracia", op. cit., pp. 88 y ss. 
motivaciones reales de la oposición al cambio, es decir, qué intereses concretos se benefician cuando se reduce la soberanía del pueblo a una expresión esencialmente formal y puntual en el tiempo. Quienes los usan ocultan sistemáticamente las experiencias que acreditan, en muchos casos, la utilidad de estas herramientas participativas y también el hecho de que los supuestos riesgos de la participación politica directa - su posible empleo demagógico y el peligro para los derechos de las minorias son algunos de los más aludidos también están presentes, al menos en igual medida, en la democracia representativa. Es más, los mecanismos representativos añaden a los ya citados otros riesgos que les son propios, como la partitocracia, el nepotismo y en general, la corrupción ${ }^{66}$.

\section{CONCLUSIONES.}

Lo cierto es que el constituyente de 1978 se vio muy inclinado, por circunstancias históricas, a potenciar las instituciones representativas y los partidos políticos, y creyó que una buena medida en esta línea era limitar la participación popular directa. La decisión puede ser entendible en términos estrictamente históricos, pero no es menos cierto que treinta años antes, el constituyente italiano, a la salida también de un régimen totalitario apostó por un cierto equilibrio entre democracia parlamentaria y participación directa sin que se hayan registrado en consecuencia los efectos perniciosos pronosticados por los detractores de ésta67. Cabe la crítica a nuestros constituyentes por la pérdida de una oportunidad histórica para diseñar una democracia más participativa, en la linea del anteproyecto; pero ha de ser una critica matizada en función del complicado contexto en que fue concebida y desarrollada la transición de España a la democracia, y cabe entender la posición de los constituyentes, aunque se desapruebe desde una perspectiva ex post. En cambio, resulta menos comprensible que después de casi cuarenta años de vigencia constitucional no se hayan modificado estos esquemas originales ni se haya planteado una reforma de la Constitución para desarrollar en clave participativa el principio democrático que solemnemente proclama y que le sirve de inspiración, máxime teniendo en cuenta el creciente distanciamiento entre la ciudadanía y su representación política.

La limitación a que el constituyente sometió a las instituciones de participación directa fue tan intensa que, en algunos puntos, el resultado puede suponer un cuestionamiento del principio de soberania popular (art. 1.2 CE) y un desmentido del mandato que la propia Constitución impone a los poderes públicos de facilitar la participación de todos los ciudadanos en la vida política (art. 9.2 CE) ${ }^{68}$. El problema se visualiza de modo claro en el diseño constitucional

\footnotetext{
66 Roberto Uriarte Torrealday, "Notas en torno a la admisibilidad constitucional de consultas populares de ámbito autonómico", en Revista Vasca de Administración Pública, núm. 82, 2008, p. 239.

67 Antonio Torres del Moral, "El Estado español como Estado social y democrático de Derecho y como democracia representativa y pluralista”, op. cit., pp. 45-46.

68 Miguel Ángel Presno Linera, "La participación ciudadana en el procedimiento legislativo como parte de la esencia y valor de la democracia", op. cit., p. 99, en referencia a la exclusión de la iniciativa popular para la reforma de la Constitución. En igual sentido, Antonio Torres del Moral, "El Estado español como Estado social y democrático de Derecho y como democracia representativa y
} 
del referendo consultivo (art. $92 \mathrm{CE}$ ), pues resulta paradójico que cuando se pregunta directamente al titular de la soberanía su contestación no sea vinculante para quienes detentan poderes del Estado emanados de la misma; a no ser, claro está, que se acepte que el soberano solo actúa en condición de tal en el momento en que es llamado a participar en el proceso electoral. Pero también en la exclusión de la iniciativa popular para la reforma constitucional (art. 166, en relación con el art. $87 \mathrm{CE}$ ), ya que no es menos contradictorio que los ciudadanos no puedan participar en la fase de iniciativa cuando se trata de una cuestión tan relevante para el ordenamiento jurídico como es la reforma de la Constitución. Desde esta óptica, podría incluso afirmarse que la Constitución de 1978 es incoherente cuando expresa con vigor el principio democrático, que parte del reconocimiento de la soberanía popular (art. 1.2 CE) y tiene sus correlatos en los principios de participación ciudadana (arts. $9.2 \mathrm{CE}$, art. $23 \mathrm{CE}$ ) y de pluralismo politico (art. 1.1 CE, art. $6 \mathrm{CE}$ ), e impide al tiempo ciertas expresiones esenciales de dicha soberanía y dificulta sobremanera otras.

A veces se justifica el criterio restrictivo con que la Constitución aborda las instituciones de participación politica directa con el argumento de que la elección de los constituyentes fue articular una democracia participativa. Sin embargo, este argumento a lo sumo explica su actuación, pero no la justifica. La afirmación de que la regulación sumamente cautelosa de estos mecanismos pone de manifiesto una opción constitucional por la democracia representativa es difícilmente objetable; lo que no significa, desde luego, que fuese una condición sine qua non de la misma. La democracia representativa, contemplada desde un punto de vista participativo, se enriquece con el reconocimiento y el estímulo de la participación directa. Y la misma Constitución ofrece elementos más que suficientes, en su apuesta decidida por el principio democrático y en el desarrollo que del mismo hace, para defender no solo una interpretación lo más favorable posible al impulso de la participación política directa, dentro de los cauces constitucionales, sino también la conveniencia de una reforma constitucional que elimine las contradicciones internas apuntadas.

Enviado el (Submission Date): 14/01/2018

Aceptado el (Acceptance Date): 16/04/2018

pluralista", op. cit., p. 44, y, en referencia concreta al referendo consultivo, "Derecho de participación política: (III) Instituciones de participación política directa", en V. Gimeno Sendra, A. Torres del Moral, P. Morenilla Allard y M. Díaz Martínez, Los derechos fundamentales y su protección jurisdiccional, Colex, Madrid, 2007, p. 315. 